Revista Eletrônica de Ciência Administrativa (RECADM) - ISSN 1677-7387

Faculdade Cenecista de Campo Largo - Coordenação do Curso de Administração v. 4, n. 1, maio/2005 - http://revistas.facecla.com.br/index.php/recadm/

\title{
RESPONSABILIDADE SOCIAL CORPORATIVA: UMA CONTRIBUIÇÃO DAS EMPRESAS PARA O DESENVOLVIMENTO SUSTENTÁVEL
}

Maria Elisabeth Pereira Kraemer (beth.kraemer@terra.com.br)

Contadora, CRC/SC no 11.170, Professora e integrante da Equipe de Ensino e Avaliação na Pró-Reitoria de Ensino da UNIVALI - Universidade do Vale do Itajaí. Mestre em Relações Econômicas Sociais e Internacionais pela Universidade do Minho-Portugal. Doutoranda em Ciências Empresariais pela Universidade do Museu Social da Argentina. Integrante da Corrente Científica Brasileira do Neopatrimonialismo e da ACIN Associação Científica Internacional Neopatrimonialista.

\section{RESUMO}

O exercício da responsabilidade social corporativa está associado à noção de sustentabilidade, que visa conciliar as esferas econômica, ambiental e social na geração de um cenário compatível à continuidade e à expansão das atividades das empresas no presente e no futuro. A responsabilidade social corporativa passa a ser considerada um elemento importante para o desenvolvimento dos negócios e para estabelecer relações positivas das empresas com as assim chamadas partes interessadas (stakeholdwers). Assim, as empresas são impulsionadas a adotar novas posturas diante de questões ligadas à ética e à qualidade da relação empresas-sociedade. Estas questões vêm influenciando, e em muitos casos impondo, mudanças nas dinâmicas de mercado e no padrão de concorrência e de competitividade, a exemplo das preocupações ligadas ao meio ambiente. Não se deve pensar em sustentabilidade como algo restrito ao meio ambiente, assim como responsabilidade social não se limita a ações ou investimentos em projetos sociais. Os dois conceitos estão intrinsecamente ligados. Uma empresa que pretenda perenizar seu negócio deverá adotar uma estratégia que contemple o que os ingleses chamam de triple bottom line (tríplice conta de resultados), ou seja, gerar valor nas dimensões econômica, ambiental e social. Da mesma forma, responsabilidade social corporativa significa entender e agir em resposta a essa nova demanda da sociedade, que é a de que o valor gerado por uma empresa se reflita em benefícios não somente para seus acionistas, mas que tenha também um impacto positivo para o conjunto dos afetados por suas operações, em particular o meio ambiente e a comunidade (seus próprios funcionários e o restante da sociedade), respeitando sua cultura e agindo de forma ética e transparente.

Palavras-chave: Desenvolvimento Sustentável, Empresas, Responsabilidade Social 
Revista Eletrônica de Ciência Administrativa (RECADM) - ISSN 1677-7387

Faculdade Cenecista de Campo Largo - Coordenação do Curso de Administração v. 4 , n. 1, maio/2005 - http://revistas.facecla.com.br/index.php/recadm/

\title{
CORPORATE SOCIAL RESPONSIBILITY: A CONTRIBUTION OF THE COMPANIES FOR THE MAINTAINABLE DEVELOPMENT
}

\begin{abstract}
The exercise of the corporate social responsibility is associated to the sustained notion, which seeks to reconcile the economic, environmental and social spheres in the generation of compatible scenery to the continuity and the expansion of the activities of the companies in the present and in the future. The corporate social responsibility becomes considered an important element for the development of the business and to establish positive relationships of the companies with the so-called interested parts (stockholders). Thus, the companies are impelled to adopt new postures in face of subjects linked to the ethics and the quality of the relationship company-society. These subjects come influencing, and in many cases imposing, changes in the market dynamics and in the competition pattern and of competitiveness, as for example the concern about the environment. One should not think of sustained as something restricted to the environment, as well as social responsibility it is not limited to actions or investments in social projects. The two concepts are tied up intrinsically. A company that intends to sustain forever its business should adopt a strategy that contemplates what English call triple bottom line (triple counts of results), that is to say to generate value in the economic, environmental and social dimensions. In the same way, corporate social responsibility means to understand and to act in response to that new demand of the society, that is that the value generated by a company is reflected in benefits not only for its shareholders, but that also has a positive impact for the group affected by its operations, in particular the environment and the community (its own employees and the remaining of the society), respecting its culture and acting in an ethical and transparent way.
\end{abstract}

Key-words: Maintainable Development, Companie, Social Responsibility

\section{1 - Introdução}

A concepção de responsabilidade social por parte das empresas vem sendo bastante difundida. Especialmente nos países mais desenvolvidos, as empresas enfrentam, crescentemente, novos desafios impostos pelas exigências dos consumidores, pela pressão de grupos da sociedade organizada e por legislações e regras comerciais que demandam, por exemplo, proteção ambiental, produtos mais seguros e menos nocivos à natureza e o cumprimento de normas éticas e trabalhistas em todos os locais de produção e em toda a cadeia produtiva.

A responsabilidade social corporativa, segundo Young (2004), definitivamente se tornou uma importante ferramenta para a sustentabilidade das organizações. Hoje, os conceitos que norteiam uma gestão socialmente responsável - a relação ética e 
Revista Eletrônica de Ciência Administrativa (RECADM) - ISSN 1677-7387

Faculdade Cenecista de Campo Largo - Coordenação do Curso de Administração v. 4, n. 1, maio/2005 - http://revistas.facecla.com.br/index.php/recadm/

transparente com todos os públicos que se relacionam com a empresa para o desenvolvimento do seu negócio e da sociedade, preservando-se os recursos ambientais e humanos para as gerações futuras - trazem vários benefícios para as organizações.

Na primeira metade do século XX, cientes da importância do seu papel social, as empresas passaram a se mostrar mais comprometidas com todos à sua volta, com a comunidade. Surgiram, então, os investidores sociais, que aplicam seus próprios recursos em projetos de interesse público, não através apenas da prática da caridade, mas por meio de ações voluntárias, planejadas e acompanhadas de perto. Tinham, e ainda têm, como objetivo melhorar a qualidade de vida dos cidadãos e fortalecer laços de confiança com eles.

Com o propósito de explorar o tema este trabalho apresenta: Conceito e definição da responsabilidade social corporativa; Grupos de interesses ou stakeholders; Objetivos da responsabilidade social corporativa; Princípios básicos da responsabilidade social corporativa; Marco referencial da responsabilidade social corporativa e Responsabilidade social como cultura empresarial.

\section{2 - Conceito e definição de responsabilidade social corporativa}

\section{1 - Conceito}

Conforme afirmam Shommer (2000) e Shommer, Rocha, Fischer (1999), o conceito de responsabilidade social corporativa parte do princípio de que a atividade empresarial contempla compromissos com toda a cadeia produtiva da empresa, como, por exemplo: clientes, funcionários e fornecedores, bem como as comunidades, o ambiente e a sociedade. Esta concepção se relaciona com a teoria dos stakeholders-os indivíduos ou grupos que dependem da organização para alcançar suas metas e dos quais a empresa depende para funcionar.

A responsabilidade social corporativa representa o compromisso com a idéia de organização como conjunto de pessoas que interagem com a sociedade. Assume o princípio de que as organizações têm sua origem e seus fins essenciais nas pessoas, as quais se organizam e se dispõem em diversos grupos de interesses, com peculiaridades e distintos tipos de relação. Contempla o impacto da ação da empresa em sua tríplice dimensão: econômica, social e ambiental, tendo como meta principal a consecução do desenvolvimento sustentável.

Em torno do conceito de responsabilidade social corporativa, de acordo com AECA (2004), existem vários termos relacionados, dentre os quais destacamos os seguintes:

$\rightarrow$ Ação social: ajuda voluntária, expressada em recursos econômicos ou de outro tipo, outorgada pelas empresas a projetos externos de caráter filantrópico e desenvolvimento 
Revista Eletrônica de Ciência Administrativa (RECADM) - ISSN 1677-7387

Faculdade Cenecista de Campo Largo - Coordenação do Curso de Administração v. 4, n. 1, maio/2005 - http://revistas.facecla.com.br/index.php/recadm/

socioeconômico (assistência social, saúde, educação, etc). A ação social é um dos diversos comportamentos socialmente responsáveis que a empresa pode acometer.

$\rightarrow$ Auditoria social: avaliação sistemática do impacto social de uma empresa em relação a certas normas e expectativas.

$\rightarrow$ Capital relacional (capital social): expressão do grau de responsabilidade e integração social das organizações, medido em termos de capacidade relacional com os distintos grupos de interesses. Alguns autores consideram o capital relacional como um dos componentes do capital intelectual.

$\rightarrow$ Código de conduta: expressão formal de valores e boas práticas da organização, enunciado com caráter orientador e normativo e com categoria de preceito a cumprir por todos os integrantes da corporação. Às vezes também se aplica aos fornecedores e a outros prestadores de serviços.

$\rightarrow$ Código de bom governo: pronunciamento formal de valores e boas práticas dos órgãos de gestão e administração da organização, enunciado com dignidade de preceito a cumprir por todas as pessoas que compõem ditos órgãos, de maneira muito especial o Conselho de Administração.

$\rightarrow$ Desenvolvimento sustentável: modelo de desenvolvimento que busca compartilhar a exploração racional de recursos naturais e sua regeneração, eliminando o impacto nocivo da ação do ser humano, em geral, e dos processos produtivos, em particular, para satisfazer as necessidades das gerações presentes sem pôr em perigo a satisfação daquelas que possam ser apresentadas pelas gerações futuras.

$\rightarrow$ Empresa cidadã: Concepção de empresa como membro integrante da sociedade, com o dever de promover seu desenvolvimento e a preservação do entorno vital onde realiza sua atividade. O cumprimento de suas obrigações como cidadão corporativo é uma forma de alcançar a legitimidade na sociedade da qual faz parte.

$\rightarrow$ Ética empresarial: é o estudo e a aplicação da moral ao mundo da empresa. Compreende o conjunto de valores, normas e providências que as organizações vinculam a seus membros em forma de ideais compartilhados e obrigações, em torno do que é bem e mal, do que é correto e incorreto.

$\rightarrow$ Filantropia estratégica: ação social da empresa, formulada e implantada sobre a base de um planejamento estratégico de negócio, associando a ação filantrópica a alguns benefícios determinados em termos econômicos e de vantagem competitiva.

$\rightarrow$ Gestão ambiental: gestão orientada à prevenção, redução, minimização e eliminação do impacto ambiental negativo que ocasiona ou pode ocasionar a atividade da empresa.

$\rightarrow$ Marketing com causa social: campanha com apoio da comercialização de produtos e serviços oferecidos por países com vistas ao desenvolvimento e organizações não governamentais que canalizam ajuda a ditos países. 
Revista Eletrônica de Ciência Administrativa (RECADM) - ISSN 1677-7387 Faculdade Cenecista de Campo Largo - Coordenação do Curso de Administração v. 4, n. 1, maio/2005 - http://revistas.facecla.com.br/index.php/recadm/

$\rightarrow$ Reputação corporativa: reconhecimento público alcançado, expressão, em certa medida, de legitimidade social.

$\rightarrow$ Sustentabilidade: expressão do impacto de atividade de empresa na tríplice dimensão: econômica, social e ambiental. Compromisso com o modelo de desenvolvimento sustentável que se pode alcançar por meio da responsabilidade social corporativa. Capacidade ou qualidade para alcançar o desenvolvimento sustentável.

$\rightarrow$ Tríplice conta de resultados (triple bottom line): é aquela que representa, em termos quantitativos, o valor econômico, o valor para o desenvolvimento social ou para o meio ambiente que as empresas criam ou destroem. Este conceito reflete a importância de considerar as conseqüências econômicas e também ambientais e sociais das decisões que tomam as organizações.

\section{2 - Definição}

Apesar de a expressão responsabilidade social corporativa não possuir uma definição consensual, pode ser entendida como a maneira ética de condução dos negócios da empresa de forma que esta se torne co-responsável pelo desenvolvimento social.

A responsabilidade social corporativa é o compromisso voluntário das empresas com o desenvolvimento da sociedade e a preservação do meio ambiente, desde sua composição social e um comportamento responsável com as pessoas e os grupos sociais aos quais se integram.

De acordo com AECA (2004), ela centra sua atenção na satisfação das necessidades dos grupos de interesse através de determinadas estratégias, cujos resultados têm que ser medidos, verificados e comunicados adequadamente. Vai além do mero cumprimento da norma legal estabelecida e da obtenção de resultados exclusivamente econômicos em curto prazo. Supõe um planejamento do tipo estratégico que afeta a tomada de decisões e as operações de toda organização, criando valor em longo prazo e contribuindo significativamente para obtenção de vantagens competitivas duradouras.

Para Almeida (2003), é o compromisso das empresas em contribuir para o desenvolvimento econômico sustentável, trabalhando seus funcionários e suas famílias, a comunidade local e a sociedade para melhorar sua qualidade de vida. A responsabilidade social corporativa inclui direitos humanos, direitos trabalhistas, proteção ambiental, relações com os fornecedores e o monitoramento dos direitos dos stakeholders, conforme é demonstrado na figura 1.

Figura 1 - Definição de responsabilidade social corporativa 
Revista Eletrônica de Ciência Administrativa (RECADM) - ISSN 1677-7387

Faculdade Cenecista de Campo Largo - Coordenação do Curso de Administração v. 4 , n. 1, maio/2005 - http://revistas.facecla.com.br/index.php/recadm/

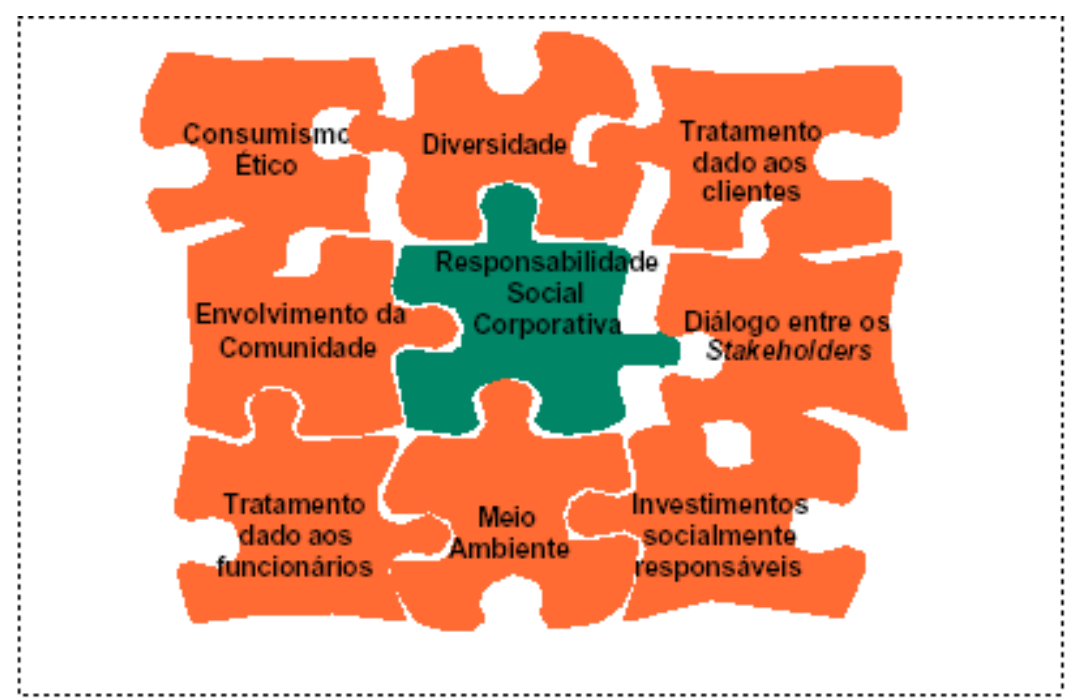

Fonte: Almeida (2003)

Os elementos relacionados abaixo, de acordo com AECA (2004), facilitam uma definição mais precisa de responsabilidade social corporativa:

$\rightarrow$ Responsabilidade: capacidade para reconhecer, aceitar e estabelecer respostas nas conseqüências de um comportamento realizado consciente e livre.

$\rightarrow$ Social: qualidade de pessoa como elemento integrante de um sistema social ou coletivo de indivíduos.

$\rightarrow$ Corporação: entidade de interesse público,comumente associada a um projeto econômico, em particular a empresa.

$\rightarrow$ Compromisso voluntário: obrigação contraída por vontade própria sem interferência de nenhuma classe.

$\rightarrow$ Organização: conjunto de pessoas estabelecido, institucionalizado e estruturado adequadamente, dotado de meios para alcançar determinados fins.

$\rightarrow$ Sociedade: agrupamento natural de pessoas que constituem unidade distinta de cada um de seus indivíduos, com o fim de cumprir, mediante mútua cooperação, todos ou alguns dos fins da vida.

$\rightarrow$ Meio ambiente: entorno físico natural, incluídos o ar, a água, a terra, a flora, a fauna e os recursos renováveis, tais como os combustíveis fósseis e os minerais.

$\rightarrow$ Pessoa: indivíduo da espécie humana.

$\rightarrow$ Grupos de interesses, partes interessadas ou stakeholders: grupos de pessoas ou indivíduos afetados de uma ou outra forma pela existência ou ação das organizações e com algum interesse legítimo sobra as mesmas.

Pode-se concluir que responsabilidade social corporativa, segundo o Instituto Ethos (2001), relaciona-se à capacidade da empresa de atender simultaneamente os interesses dos diferentes públicos com os quais ela se inter-relaciona, sendo capaz de incorporá-los ao planejamento de suas atividades. Isto significa que a empresa é socialmente responsável quando consegue gerar valor não apenas para seus 
Revista Eletrônica de Ciência Administrativa (RECADM) - ISSN 1677-7387 Faculdade Cenecista de Campo Largo - Coordenação do Curso de Administração v. 4, n. 1, maio/2005 - http://revistas.facecla.com.br/index.php/recadm/

proprietários e acionistas, mas sim para todos os demais públicos com os quais ela se relaciona: empregados, fornecedores, clientes, governo, meio ambiente e comunidade.

\section{3 - Grupos de interesses ou stakeholders}

As partes interessadas ou stakeholders são qualquer grupo dentro ou fora da organização que tem interesse no desempenho da empresa. Há uma tendência cada vez maior em se considerar stakeholder quem se julgue como tal, em cada situação. A empresa deve procurar fazer um mapeamento dos stakeholders envolvidos, conforme a figura 2 .

Figura 2 - Quem são os seus stakeholders?

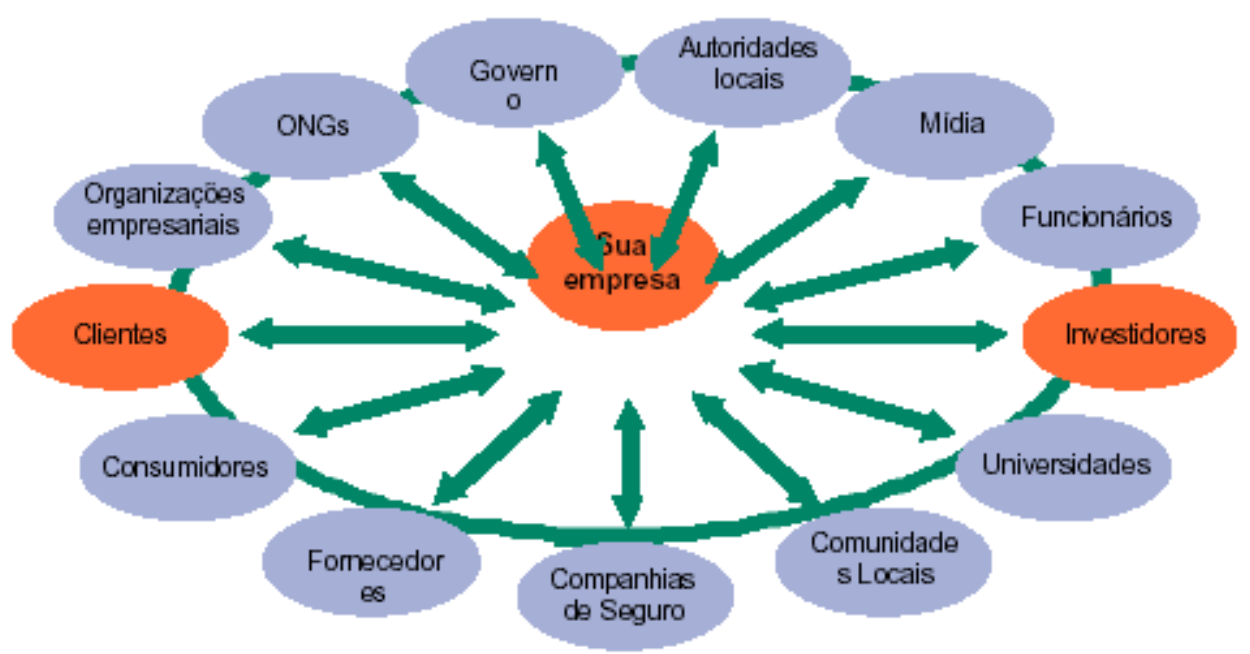

Fonte: Almeida (2003)

A responsabilidade social interna focaliza o público-interno da empresa, seus empregados e seus dependentes, ou seja, os beneficiários internos da empresa, sem os quais a organização não pode sobreviver. Por outro lado, a responsabilidade social empresarial externa procura atuar na sociedade na qual a empresa está inserida, junto a todos os seus públicos ou beneficiários externos (fornecedores, clientes atuais, potenciais clientes, opinião pública, governo, sociedade, etc.) e, conseqüentemente, a empresa obtém maior visibilidade e admiração frente a públicos relevantes para sua atuação.

As relações construídas com os públicos interno e externo, de forma a satisfazer as suas necessidades e interesses, gerando valor para todos, asseguraram a sustentabilidade em longo prazo dos negócios, por estarem sincronizadas com as novas dinâmicas que afetam a sociedade e o mundo empresarial. Este envolvimento da organização na prática da responsabilidade social gera sinergias, precisamente com os públicos dos quais a empresa depende, fortalecendo o seu desempenho global. Uma 
Revista Eletrônica de Ciência Administrativa (RECADM) - ISSN 1677-7387

Faculdade Cenecista de Campo Largo - Coordenação do Curso de Administração v. 4, n. 1, maio/2005 - http://revistas.facecla.com.br/index.php/recadm/

empresa adquire o "status" de empresa-cidadã quando atua em ambas as dimensões (responsabilidade empresarial interna e externa).

A responsabilidade social da empresa está estritamente ligada ao tipo de relacionamento desta com os seus interlocutores. A natureza desta relação vai depender muito das políticas, valores, cultura e, sobretudo, da visão estratégica que prevalecem no centro da organização e no atendimento a essas expectativas.

Os stakeholders suscitam um elenco de compromissos a serem observados pelas empresas que desejem ser publicamente reconhecidas como socialmente responsáveis e, associados a eles, os temas relacionados no quadro 1 vêm sendo atualmente tratados pelo Instituto Ethos.

Quadro 1 - Temas tratados atualmente pelo Instituto Ethos em relação à responsabilidade social corporativa

\begin{tabular}{|c|c|c|}
\hline \multirow{2}{*}{$\begin{array}{l}\text { VALORES E } \\
\text { TRANSPARÊNCIA }\end{array}$} & $\begin{array}{l}\text { Auto-regulação } \\
\text { conduta }\end{array}$ & $\begin{array}{l}\text { - Compromissos éticos } \\
\text {-Enraizamento na } \\
\text { organizacional }\end{array}$ \\
\hline & $\begin{array}{l}\text { Relações transparentes } \\
\text { com a sociedade }\end{array}$ & $\begin{array}{l}\text {-Diálogo com as partes } \\
\text { interessadas } \\
\text {-Relações com a concorrência } \\
\text {-Balanço social }\end{array}$ \\
\hline \multirow{3}{*}{$\begin{array}{l}\text { PÚBLICO } \\
\text { INTERNO }\end{array}$} & Diálogo e participação & $\begin{array}{l}\text {-Relações com os sindicatos } \\
\text {-Gestão participativa } \\
\text {-Participação nos resultados e } \\
\text { bonificações }\end{array}$ \\
\hline & Respeito ao indivíduo & $\begin{array}{l}\text {-Compromisso com o futuro das } \\
\text { crianças } \\
\text {-Valorização da diversidade }\end{array}$ \\
\hline & $\begin{array}{l}\text { Trabalho decente } \\
\text { respeito ao trabalhador }\end{array}$ & $\begin{array}{l}\text {-Compromisso frente às } \\
\text { demissões } \\
\text {-Compromisso com } \\
\text { desenvolvimento profissional e a } \\
\text { empregabilidade } \\
\text {-Cuidados com a saúde, } \\
\text { segurança e condições de } \\
\text { trabalho } \\
\text {-Preparação para a aposentadoria } \\
\text {-Política de remuneração, } \\
\text { benefícios e carreira }\end{array}$ \\
\hline \multirow[t]{2}{*}{ MEIO AMBIENTE } & $\begin{array}{l}\text { Gerenciamento } \\
\text { impacto ambiental }\end{array}$ & $\begin{array}{l}\text {-Gerenciamento do impacto no } \\
\text { meio serviços ambiente do ciclo } \\
\text { de vida dos produtos e } \\
\text {-Minimização de entradas e } \\
\text { saídas de materiais }\end{array}$ \\
\hline & \begin{tabular}{|l|} 
Responsabilidade frente \\
às gerações futuras
\end{tabular} & $\begin{array}{l}\text {-Comprometimento da empresa } \\
\text { com a causa ambiental } \\
\text {-Educação ambiental }\end{array}$ \\
\hline
\end{tabular}


Revista Eletrônica de Ciência Administrativa (RECADM) - ISSN 1677-7387

Faculdade Cenecista de Campo Largo - Coordenação do Curso de Administração

v. 4, n. 1, maio/2005 - http://revistas.facecla.com.br/index.php/recadm/

\begin{tabular}{|c|c|c|}
\hline FORNECEDORES & $\begin{array}{lr}\text { Seleção, avaliação } & \text { e } \\
\text { parcerias } & \text { com } \\
\text { fornecedores } & \end{array}$ & $\begin{array}{l}\text {-Critério de seleção e avaliação de } \\
\text { fornecedores } \\
\text {-Trabalho infantil na cadeia } \\
\text { produtiva } \\
\text {-Relações com os trabalhadores } \\
\text { terceirizados } \\
\text {-Apoio ao desenvolvimento de } \\
\text { fornecedores }\end{array}$ \\
\hline $\begin{array}{l}\text { CONSUMIDORES/ } \\
\text { CLIENTES }\end{array}$ & $\begin{array}{l}\text { Dimensão social do } \\
\text { consumo }\end{array}$ & $\begin{array}{l}\text {-Política de marketing e } \\
\text { comunicação comercial } \\
\text {-Excelência do atendimento } \\
\text {-Conhecimento dos danos } \\
\text { potenciais dos produtos e serviços }\end{array}$ \\
\hline \multirow[t]{3}{*}{ COMUNIDADES } & $\begin{array}{l}\text { Relações com } \\
\text { comunidade local }\end{array}$ & $\begin{array}{l}\text {-Gerenciamento do impacto } \\
\text { da empresa na comunidade } \\
\text { do entorno } \\
\text {-Relações com organizações } \\
\text { locais }\end{array}$ \\
\hline & Ação social & $\begin{array}{l}\text {-Financiamento } \\
\text {-Gestão da ação social } \\
\text {-Foco e alcance da ação social } \\
\text {-Integração entre empresa e ação } \\
\text { social }\end{array}$ \\
\hline & Trabalho voluntário & -Estímulo ao voluntariado \\
\hline \multirow[t]{2}{*}{$\begin{array}{l}\text { GOVERNO E } \\
\text { SOCIEDADE }\end{array}$} & Transparência política & $\begin{array}{l}\text {-Contribuições para campanhas } \\
\text { políticas } \\
\text {-Práticas anticorrupção e própria }\end{array}$ \\
\hline & Liderança social & $\begin{array}{l}\text {-Liderança e influência social } \\
\text {-Participação em projetos sociais } \\
\text { governamentais }\end{array}$ \\
\hline
\end{tabular}

Fonte: Indicadores Ethos de Responsabilidade Social Empresarial, versão 2003.

\section{4 - Objetivos da responsabilidade social corporativa}

A responsabilidade social corporativa deve ser útil para atender as necessidades dos distintos grupos de interesses, desde um comportamento eficiente e adequado na tríplice dimensão: econômica, social e ambiental da empresa. Por isso, o objetivo básico da responsabilidade social corporativa, segundo AECA (2004), é fornecer elementos de direção e gestão consistentes para:

$\rightarrow$ Dotar a empresa de uma base conceitual sólida desenvolver o modelo de empresa cidadã e de sua contribuição para o desenvolvimento sustentável.

$\rightarrow$ Inovar e melhorar os processos de direção, gestão, medição e informação das empresas, para que estas tenham em conta a citada tríplice dimensão de sua atividade e a satisfação de necessidades dos grupos de interesses.

$\rightarrow$ Fazer com que as empresas gerem externalidades socialmente responsáveis.

Conforme os objetivos acima, a responsabilidade social corporativa deve permitir, de acordo com AECA (2004): 
Revista Eletrônica de Ciência Administrativa (RECADM) - ISSN 1677-7387 Faculdade Cenecista de Campo Largo - Coordenação do Curso de Administração v. 4 , n. 1, maio/2005 - http://revistas.facecla.com.br/index.php/recadm/

$\rightarrow$ Introduzir melhoras nos processos internos da empresa, em todos os níveis, com um sistema de gestão integral que considere os aspectos econômicos, sociais e ambientais e tenha em conta as necessidades manifestadas dos distintos grupos de interesse.

$\rightarrow$ Potenciar as vantagens competitivas da empresa em aspectos tão relevantes como, por exemplo: fortalecimento da reputação corporativa, fidelidade do cliente, incrementos da qualidade e da produtividade, incremento da capacidade de atrair e reter talento e incremento da capacidade de atrair recursos financeiros.

$\rightarrow$ Fornecer informação completa e confiável da atividade da organização em sua tríplice dimensão, útil para todas as partes interessadas.

$\rightarrow$ Desenvolvimento econômico da empresa, mediante a geração suficiente de benefícios.

\section{5 - Princípios básicos da responsabilidade social corporativa}

Os princípios básicos constituem regras fundamentais que regem o comportamento socialmente responsável das organizações. Sua determinação e aplicação estão em congruência com o conceito, os objetivos da responsabilidade social corporativa e as necessidades dos grupos de interesses.

Os princípios básicos que propõe a AECA (2004) são: transparência, materialidade, verificabilidade, visão ampla, melhoria contínua e natureza social da organização.

5.1 - Transparência - é a peça básica da responsabilidade social corporativa. Está fundamentada no acesso a informação que a organização proporciona sobre seu comportamento social e que é permeável às sociais. Um instrumento essencial da transparência é a comunicação dos aspectos ligados à responsabilidade social corporativa, mediante um relatório dirigido aos seus grupos de interesses e que se reflete o compromisso e a participação dos mesmos.

5.2 - Materialidade -presume-se que a organização deve ter em conta as necessidades e expectativas das partes interessadas na tomada de decisões, afrontando todas as dimensões da responsabilidade social corporativa, assim como todas as suas atividades e impactos, diretos e indiretos. Para obter um adequado nível de conhecimento do que é ou não material em seu comportamento a respeito da responsabilidade social corporativa, as organizações devem manter um adequado fluxo de relação com os grupos de interesse da mesma. Uma organização deve entender que a responsabilidade social corporativa afeta todas as atividades da empresa, assim como o conceito mais amplo de sua entidade. A inaplicação da responsabilidade social corporativa a alguma 
Revista Eletrônica de Ciência Administrativa (RECADM) - ISSN 1677-7387

Faculdade Cenecista de Campo Largo - Coordenação do Curso de Administração v. 4, n. 1, maio/2005 - http://revistas.facecla.com.br/index.php/recadm/

entidade sobre a qual exerce influência ou sobre uma atividade implica uma inadequada aplicação do princípio de materialidade.

5.3- Verificabilidade - as atuações socialmente responsáveis da entidade devem se submeter a uma verificação externa. A transparência e a verificabilidade são princípios necessários para obter um adequado nível de credibilidade. A verificabilidade está fundamentada na possibilidade de que uma auditoria independente possa comprovar as atuações da empresa. O relatório final de um auditor independente pode proporcionar indícios sobre a verificabilidade das atuações.

5.4 - Visão ampla - a organização deve centrar seus objetivos de responsabilidade social corporativa no contexto de sustentabilidade mais amplo possível. Deve considerar o impacto que produz nos âmbitos local, regional e global, com um sentido claro de herança para futuras gerações. A situação no contexto de sustentabilidade estará em função de múltiplos fatores. Os mais relevantes são a atividade, a localização e o tamanho da organização. O princípio de visão ampla supõe que as organizações determinem seu impacto macroeconômico, ampliando a tradicional visão da empresa em nível microeconômico.

5.5 - Melhora contínua - a responsabilidade social corporativa é ligada à idéia de gestão continuada, que tem por objetivo principal a sobrevivência da organização. Uma atividade puramente especulativa, com o propósito exclusivo de maximizar em curto prazo o benefício econômico, sem considerar a consecução de outro tipo de objetivos em médio e longo prazos (plural), é por definição uma atividade carente de responsabilidade social corporativa. As estratégias de responsabilidade social corporativa pretendem assegurar a viabilidade do projeto empresarial em longo prazo, promovendo uma relação simbólica com o entorno social e com o meio ambiente.

5.6 - Natureza social da organização - a responsabilidade social corporativa está estabelecida na imagem e no reconhecimento da natureza social das organizações como valor que prevalece sobre qualquer outra consideração do tipo econômico ou técnico. Destaca o valor e o papel do ser humano como ente individual e social, origem e fim da organização. As estratégias de responsabilidade social corporativa pretendem assegurar que a organização se estrutura sobre a base de sua natureza social e não sobre valores de índole estritamente técnica-econômica.

\section{6 - Marco referencial da responsabilidade social corporativa}


Revista Eletrônica de Ciência Administrativa (RECADM) - ISSN 1677-7387 Faculdade Cenecista de Campo Largo - Coordenação do Curso de Administração v. 4, n. 1, maio/2005 - http://revistas.facecla.com.br/index.php/recadm/

Desde o final da Segunda Guerra Mundial tem havido no cenário internacional uma forte preocupação com a definição de direitos e de normas para regular as várias esferas da vida social. A seguir, destacamos os principais marcos referenciais sobre 0 assunto.

\section{1 - A Declaração Universal dos Direitos Humanos da ONU}

É um dos documentos que sistematiza um conjunto de direitos que foram sendo conquistados e ampliados pelos povos desde o século XVII e que finalmente foram reconhecidos como universais e validados pelos países membros da Organização das Nações Unidas (ONU) em 1948. Criada em 1945, logo após o fim da Segunda Guerra Mundial, com a missão de garantir a paz no mundo, a ONU viu na proclamação desses direitos uma condição indispensável à realização de seus objetivos.

A Declaração Universal dos Direitos Humanos da ONU é o primeiro grande marco institucional para o debate sobre a responsabilidade social. Com 30 artigos, a Declaração traz direito reconhecido como o ideal a ser atingido por todos os povos, reunindo, basicamente, uma série de direitos políticos e civis e de direitos econômicos, sociais e culturais. Os primeiros já haviam sido parcialmente formulados em documentos anteriores, como a Declaração de Direitos do Povo de Virgínia, de 1776, e a Declaração dos Direitos do Homem e do Cidadão, da França revolucionária, em 1789. Os outros têm sua principal origem nos movimentos revolucionários e socialistas do século XIX e XX.

Os temas vão desde o direito à vida, à liberdade, à educação, à saúde e ao trabalho até a proibição de qualquer discriminação. Além disso, a Declaração da ONU recrimina práticas como escravidão e tortura e defende o direito à justiça e às liberdades de consciência e expressão.

Entre os direitos relacionados com o mundo do trabalho, podem ser destacados:

$\rightarrow$ A preocupação com a segurança pessoal (artigo $3^{\circ}$ ), que envolve necessariamente a segurança no local de trabalho.

$\rightarrow$ O repúdio ao trabalho escravo (artigo $4^{\circ}$ ) e à utilização de maus tratos.

$\rightarrow$ A defesa da liberdade de expressão e manifestação (artigo $1^{\circ}$ ) e de associação (artigo $20^{\circ}$ ), direito de toda pessoa de fundar, com outras pessoas, sindicatos e de se filiar a sindicatos para defesa dos seus interesses.

$\rightarrow$ O direito de toda pessoa a ter trabalho, escolhido livremente, em condições eqüitativas e satisfatórias.

$\rightarrow$ Direito à proteção contra o desemprego.

$\rightarrow$ Direito de receber salário igual por trabalho igual. 
Revista Eletrônica de Ciência Administrativa (RECADM) - ISSN 1677-7387 Faculdade Cenecista de Campo Largo - Coordenação do Curso de Administração v. 4 , n. 1, maio/2005 - http://revistas.facecla.com.br/index.php/recadm/

$\rightarrow$ A remuneração deve garantir ao indivíduo e à sua família uma existência com dignidade e complementada, se possível, por todos os outros meios de proteção social (artigo $23^{\circ}$ ).

$\rightarrow$ Direito ao repouso e ao lazer, a uma limitação da duração do trabalho e de receber férias periódicas pagas (artigo $24^{\circ}$ ).

A Declaração Universal dos Direitos Humanos da ONU completa 56 anos. Preparada e aprovada em dois anos e meio, foi resultado de negociação entre os integrantes da Comissão dos Direitos Humanos da ONU e da Assembléia Geral, formada na época por 56 países.

\section{2 - A Declaração da OIT sobre os princípios e direitos fundamentais do trabalho e seu seguimento}

Foi adotada pela Conferência Internacional do Trabalho da Organização Internacional do Trabalho (OIT) em sua $86^{a}$ assembléia realizada em junho de 1998 . Seu propósito principal é promover uma forte conexão entre o crescimento econômico e a justiça.

A Declaração insta o escritório da OIT a apoiar a promoção das Normas Internacionais do Trabalho, através da cooperação técnica e dos recursos disponibilizados para a investigação em todos os âmbitos de sua competência, em particular o desemprego, a formação profissional e as condições de trabalho, a fim de que, no marco de uma estratégia global de desenvolvimento econômico e social, as políticas econômicas e sociais reforcem mutuamente os componentes das atividades, visando ao estabelecimento de um desenvolvimento sustentável.

O documento é uma reafirmação universal do compromisso dos EstadosMembros e da comunidade internacional de respeitar, promover e aplicar de "boa-fé" os princípios fundamentais e direitos no trabalho referentes:

$\rightarrow$ à liberdade de associação e de organização sindical e ao reconhecimento efetivo do direito de negociação coletiva,

$\rightarrow$ à eliminação de todas as formas de trabalho forçado ou obrigatório,

$\rightarrow$ à abolição efetiva do trabalho infantil e

$\rightarrow$ à eliminação da discriminação em matéria de emprego e ocupação.

Esses direitos estão refletidos em oito Convenções fundamentais, conforme o quadro 2 . 
Revista Eletrônica de Ciência Administrativa (RECADM) - ISSN 1677-7387

Faculdade Cenecista de Campo Largo - Coordenação do Curso de Administração v. 4, n. 1, maio/2005 - http://revistas.facecla.com.br/index.php/recadm/

Quadro 2 - Direitos citados em oito Convenções Trabalhistas

\begin{tabular}{|c|c|}
\hline Liberdade sindical & Direito \\
\hline $\begin{array}{l}\text { Convenção } \mathbf{N}^{\circ} \mathbf{9 8} \\
\text { Direito de sindicalização e de } \\
\text { negociação coletiva (1949) }\end{array}$ & $\begin{array}{l}\text { Estabelece o direito de todos os trabalhadores e } \\
\text { empregadores de constituir organizações que } \\
\text { considerem convenientes e de a elas se } \\
\text { afiliarem, sem prévia autorização. Apresenta } \\
\text { também uma série de garantias para o livre } \\
\text { funcionamento dessas organizações, sem } \\
\text { ingerência das autoridades públicas. } \\
\text { O documento estipula proteção contra todo ato } \\
\text { de discriminação que reduza a liberdade } \\
\text { sindical. Também visa proteger as organizações } \\
\text { de trabalhadores e de empregadores contra atos } \\
\text { de ingerência de umas nas outras e apresenta } \\
\text { medidas para promover a negociação coletiva. }\end{array}$ \\
\hline Trabalho Forçado & Direitos \\
\hline $\begin{array}{l}\text { Convenção No } 105 \\
\text { Abolição do trabalho forçado (1957) }\end{array}$ & $\begin{array}{l}\text { Dispõe sobre a eliminação do trabalho forçado } \\
\text { ou obrigatório em todas as suas formas. } \\
\text { Admitem-se algumas exceções, tais como o } \\
\text { serviço militar, o trabalho penitenciário } \\
\text { adequadamente supervisionado e o trabalho } \\
\text { obrigatório em situações de emergência, como } \\
\text { guerras, incêndios, terremotos etc. } \\
\text { Proíbe o uso de toda forma de trabalho forçado } \\
\text { ou obrigatório como meio de coerção ou de } \\
\text { educação política; como castigo por expressão } \\
\text { de opiniões políticas ou ideológicas; a } \\
\text { mobilização de mão-de-obra; como medida } \\
\text { disciplinar no trabalho, punição por participação } \\
\text { em greves ou como medida de discriminação. }\end{array}$ \\
\hline Abolição do trabalho infantil & Direito \\
\hline $\begin{array}{l}\text { Convenção No } 138 \\
\text { Idade mínima (1973) } \\
\text { Convenção } \mathbf{N}^{\circ} \mathbf{1 8 2} \\
\text { Piores formas de trabalho infantil } \\
(1999)\end{array}$ & $\begin{array}{l}\text { Estipula que a idade mínima de admissão ao } \\
\text { emprego não deverá ser inferior à idade de } \\
\text { conclusão do ensino obrigatório. } \\
\text { Defende a adoção de medidas imediatas e } \\
\text { eficazes que garantam a proibição e a } \\
\text { eliminação das piores formas de trabalho } \\
\text { infantil. }\end{array}$ \\
\hline Eliminação da discriminação & Direito \\
\hline $\begin{array}{l}\text { Convenção } \mathbf{N}^{\circ} 100 \\
\text { lgualdade de remuneração (1951) } \\
\text { Convenção Nº } 111 \\
\text { Discriminação (emprego e ocupação, } \\
\text { 1958) }\end{array}$ & $\begin{array}{l}\text { Preconiza a igualdade de remuneração e de } \\
\text { benefícios entre homens e mulheres por } \\
\text { trabalho de igual valor. } \\
\text { Preconiza a formulação de uma política nacional } \\
\text { que elimine toda discriminação em matéria de } \\
\text { emprego, formação profissional e condições de } \\
\text { trabalho por motivos de raça, cor, sexo, religião, } \\
\text { opinião política, ascendência nacional ou origem } \\
\text { social e promoção da igualdade de } \\
\text { oportunidades e de tratamento. }\end{array}$ \\
\hline
\end{tabular}

Fonte: http://www.observatoriosocial.org.br. (2004) 
Revista Eletrônica de Ciência Administrativa (RECADM) - ISSN 1677-7387 Faculdade Cenecista de Campo Largo - Coordenação do Curso de Administração v. 4, n. 1, maio/2005 - http://revistas.facecla.com.br/index.php/recadm/

A Declaração destaca que todos os Estados-Membros estão obrigados a respeitar os direitos fundamentais que sejam objeto das convenções correspondentes, mesmo que ainda não as tenham ratificado.

No Brasil, a OIT vem promovendo a Declaração e seu conteúdo através de:

$\rightarrow$ estudos e seminários tripartites e atividades de cooperação técnica focalizadas sobre cada uma das quatro áreas de direitos,

$\rightarrow$ fórum virtual interativo sobre a Declaração e seus componentes.

De acordo com o site da OIT no Brasil (www.oitbrasil.org.br), também em parceria com o Instituto Ethos de Responsabilidade Social e Empresarial, o Fundo das Nações Unidas para a Infância (Unicef) e o Fundo de Desenvolvimento das Nações Unidas para a Mulher (Unifem), a OIT está empenhada em promover o Pacto Global, uma iniciativa da OIT com o Alto Comissariado das Nações Unidas para os Direitos Humanos (OHCHR) e o Programa das Nações Unidas para o Meio Ambiente, voltada para a subscrição de empresas a nove princípios fundamentais nas áreas de direitos humanos, trabalho e meio ambiente.

\section{3 - A Declaração Tripartite de Princípios sobre Empresas Multinacionais e Política Social da OIT}

A Declaração Tripartite de Princípios sobre Empresas Multinacionais e Política Social da OIT não é um código de conduta adotado pelas empresas ou uma pauta para as empresas. Como todas as decisões e instrumentos da OIT, é adotado por tripartites: governos, organizações de empregadores e organizações de trabalhadores.

O enfoque prático da Declaração que foi formulada em 1977 é fazer alianças, poder construir e estabelecer formas mais produtivas e criativas de abordar de maneira mais responsável as rápidas mudanças no mundo empresarial. Ela oferece uma forma de gerir as relações produtivas nos países onde as multinacionais operam. Para as empresas locais, oferecem uma oportunidade para manter e criar alianças com mercados globais. Para os governos, um campo para todas as empresas para atrair investimentos multinacionais e promover o trabalho decente. Define uma série de pontos de referência sobre as questões-chave das relações entre empresas multinacionais, o trabalho decente e o desenvolvimento. Seções do documento tratam, nesta ordem, dos seguintes temas: antecedentes e objetivos, política geral, emprego, formação, condições de trabalho e de vida e relações de trabalho.

Em 2000, a Declaração foi revisada e ampliada. O documento reafirma os Direitos Fundamentais no Trabalho e faz uma série de recomendações de alta relevância para os trabalhadores, conforme 0 site do observatório: http://www.observatoriosocial.org.br.

$\rightarrow$ Promoção do emprego: seria papel dos governos formular e executar políticas neste sentido. As empresas multinacionais deveriam colaborar com essas políticas nos países 
Revista Eletrônica de Ciência Administrativa (RECADM) - ISSN 1677-7387

Faculdade Cenecista de Campo Largo - Coordenação do Curso de Administração v. 4 , n. 1, maio/2005 - http://revistas.facecla.com.br/index.php/recadm/

onde investem, dando prioridade ao emprego, ao desenvolvimento profissional, à promoção e ao aperfeiçoamento dos trabalhadores. Essa cooperação deveria se estender também aos representantes dos trabalhadores.

$\rightarrow$ Segurança no emprego: governos e empresas multinacionais deveriam adotar medidas para assegurar emprego estável a seus trabalhadores e para respeitar as obrigações livremente negociadas em matéria de estabilidade no emprego e seguridade social.

$\rightarrow$ Formação: governos, empresas multinacionais e instâncias de representação dos trabalhadores deveriam elaborar políticas nacionais de orientação e formação profissionais) voltadas para o emprego.

$\rightarrow$ Condições de trabalho e de vida: governos, em colaboração com as empresas multinacionais, deveriam garantir as condições de trabalho suficientes para a satisfação das necessidades básicas dos trabalhadores e de suas famílias.

$\rightarrow$ Segurança e higiene: os governos deveriam assegurar que as empresas multinacionais e nacionais apliquem normas adequadas de segurança e higiene para seus trabalhadores, inclusive incorporando-as, quando possível, nos acordos coletivos com os representantes dos trabalhadores e suas organizações.

$\rightarrow$ Consultas: os governos deveriam garantir, com a legislação e a prática nacionais, a existência de um sistema de consultas regulares sobre as questões de interesse mútuo entre empregadores e os trabalhadores e seus representantes.

$\rightarrow$ Exame das reclamações: governos deveriam garantir ao trabalhador o direito de apresentar reclamação sem sofrer nenhum prejuízo e que o exame dessa reclamação tenha um procedimento adequado.

$\rightarrow$ Solução de conflitos trabalhistas: as empresas multinacionais e nacionais, com os representantes e as organizações dos trabalhadores por elas empregados, deveriam instituir um mecanismo de conciliação voluntária adequada às circunstâncias nacionais. Estes organismos deveriam possuir uma representação igual de empregadores e de trabalhadores.

A Declaração tem como objetivos interdependentes: fomentar a contribuição positiva das empresas multinacionais ao progresso econômico e social, minimizar e resolver as dificuldades que suas operações podem causar. Tudo que se faz dentro do marco da Declaração tem que obedecer às leis nacionais e também respeitar as normas internacionais.

6.4 - Diretrizes para as Empresas Multinacionais da Organização para a Cooperação e Desenvolvimento Econômico - OCDE 
Revista Eletrônica de Ciência Administrativa (RECADM) - ISSN 1677-7387 Faculdade Cenecista de Campo Largo - Coordenação do Curso de Administração v. 4, n. 1, maio/2005 - http://revistas.facecla.com.br/index.php/recadm/

Estas Diretrizes são recomendações dos governos às empresas multinacionais, que definem princípios e padrões de cumprimento voluntário, de acordo com legislações nacionais, visando promover uma conduta empresarial responsável.

São endereçadas principalmente às empresas que operam em países que a elas aderiram. Entre estes se incluem os 30 países da OCDE (Áustria, Bélgica, Canadá, Dinamarca, França, Alemanha, Grécia, Islândia, Irlanda, Itália, Luxemburgo, Holanda, Noruega, Portugal, Espanha, Suécia, Suíça, Turquia, Reino Unido, Estados Unidos, Japão, Finlândia, Austrália, Nova Zelândia, México, República Checa, Hungria, Polônia, Coréia e República Eslovaca), mais a Argentina, o Brasil e o Chile que adotaram em junho de 2000.

As Diretrizes são as únicas regras abrangentes multilateralmente endossadas pelos governos que as estabeleceram, através das quais se comprometem a ajudar na solução de problemas que surjam nas corporações empresariais. Baseiam-se em documentos da Organização Internacional do Trabalho - OIT e da ONU e têm caráter voluntário.

O documento exprime a visão compartilhada dos principais governos sobre o que estes consideram ser um bom comportamento empresarial, esperando que as empresas respeitem o conteúdo destas Diretrizes em suas operações mundiais.

Os princípios gerais das Diretrizes para as empresas multinacionais são:

$\rightarrow$ Colaborar com o progresso econômico, social e ambiental, numa lógica voltada para garantir o desenvolvimento sustentável.

$\rightarrow$ Respeitar os direitos humanos e os compromissos internacionais assumidos pelos países onde tenham unidades.

$\rightarrow$ Estimular a criação de capacidades locais em cooperação com a comunidade.

$\rightarrow$ Criar oportunidades de empregos e estimular a formação profissional.

$\rightarrow$ Abster-se de procurar ou aceitar exceções não previstas no quadro legal ou regulamentar em domínios como o meio ambiente, a saúde, a segurança, o trabalho, a tributação, os incentivos financeiros ou outros.

$\rightarrow$ Desenvolver e aplicar as boas práticas de gestão empresarial.

$\rightarrow$ Estabelecer práticas que promovam uma relação de confiança mútua entre as empresas e as sociedades.

$\rightarrow$ Divulgar para os trabalhadores as políticas da empresa e estimular que suas ações sejam adequadas a elas.

$\rightarrow$ Não perseguir trabalhadores que denunciem práticas que contrariem a lei, as Diretrizes ou as políticas da empresa.

$\rightarrow$ Estimular os fornecedores e terceirizados a ter também uma conduta empresarial adequada às Diretrizes.

$\rightarrow$ Evitar qualquer ingerência indevida em atividades políticas locais. 
Revista Eletrônica de Ciência Administrativa (RECADM) - ISSN 1677-7387 Faculdade Cenecista de Campo Largo - Coordenação do Curso de Administração v. 4, n. 1, maio/2005 - http://revistas.facecla.com.br/index.php/recadm/

Além dos princípios gerais, as Diretrizes abordam também outras questões. Uma delas, relacionada à divulgação de informações, estabelece que regularmente as empresas devem tornar públicos dados confiáveis e pertinentes sobre:

$\rightarrow$ Suas atividades, estrutura, razão social, sedes, endereços e telefones da matriz e principais filiais, participação no capital de suas filiais e nas joint-ventures, situação financeira, objetivos e resultados;

$\rightarrow$ sua contabilidade e aspectos financeiros;

$\rightarrow$ seus acionistas majoritários, membros do conselho de administração e principais diretores;

$\rightarrow$ fatores de risco relevantes e previsíveis, e sistemas de gestão de risco;

$\rightarrow$ questões de interesse direto dos trabalhadores, como alterações no processo produtivo, fechamento de unidades etc.;

$\rightarrow$ políticas de gestão da empresa, códigos de conduta nas várias áreas (meio ambiente, ética, política social etc.) e princípios e normas internacionais a que tenham aderido.

As Diretrizes destinam um capítulo específico para a questão do emprego e das relações empresariais. Nele reafirmam os temas abordados pelos Direitos Fundamentais no Trabalho e a Declaração Tripartite para Empresas Multinacionais da OIT. Além disso, as Diretrizes frisam que as empresas deverão:

$\rightarrow$ Respeitar padrões não menos favoráveis do que os observados por empresas da mesma dimensão e setor no país onde estão instaladas.

$\rightarrow$ Tomar medidas para assegurar saúde e segurança no trabalho.

$\rightarrow$ Empregar o maior número possível de pessoal local, qualificando-o em cooperação com representantes dos trabalhadores e, quando necessário, com as autoridades públicas.

$\rightarrow$ Informar aos representantes dos trabalhadores e, quando apropriado, às autoridades públicas, sobre alterações que possam afetar a vida dos trabalhadores, em especial sobre fechamento de unidades que implique em demissões coletivas. Se possível, fornecer tais informações antes mesmo de ser tomada a decisão final e cooperar para atenuar os efeitos adversos das medidas.

$\rightarrow$ Não influenciar, de modo desleal, as negociações com representantes dos trabalhadores ou não prejudicar seu direito de associação, por meio de ameaças de transferência de unidades de produção ou de trabalhadores.

$\rightarrow$ Permitir que os representantes dos trabalhadores negociem acordos coletivos de trabalho ou termos da relações entre trabalhadores e empregadores.

As diretrizes da OCDE observam ainda outros aspectos, em relação aos quais fazem recomendações às empresas multinacionais:

$\rightarrow$ Meio-ambiente: respeitar a legislação nacional, os acordos, princípios e padrões internacionais na área ambiental, contribuindo para o desenvolvimento sustentável. 
Revista Eletrônica de Ciência Administrativa (RECADM) - ISSN 1677-7387 Faculdade Cenecista de Campo Largo - Coordenação do Curso de Administração v. 4 , n. 1, maio/2005 - http://revistas.facecla.com.br/index.php/recadm/

$\rightarrow$ Combate à corrupção: não se envolver em corrupção e nem em práticas de extorsão. Contribuir para a transparência em suas atividades ligadas ao combate à corrupção e extorsão, especialmente com um diálogo aberto com seus trabalhadores e a sociedade.

$\rightarrow$ Interesses do consumidor: seguir práticas corretas e justas em suas atividades comerciais, publicitárias e de comercialização.

$\rightarrow$ Ciência e tecnologia: suas atividades devem ser compatíveis com as políticas governamentais dos países onde estão instaladas. Devem contribuir para o desenvolvimento da capacidade de inovação local e nacional e adotar práticas para difundir e transferir tecnologias e conhecimentos técnicos, levando em conta a proteção dos direitos de propriedade intelectual.

$\rightarrow$ Concorrência: evitar exercer qualquer atividade de forma a prejudicar as regras legais e regulamentares da livre concorrência.

$\rightarrow$ Tributação: cumprir com as obrigações fiscais dos países onde estão instaladas.

\section{5 - A Declaração do Rio e a Agenda 21 da ONU}

A Conferência do Rio foi o primeiro encontro global após o fim da Guerra Fria e questionava se novas políticas poderiam ser forjadas em torno de um futuro comum mundial. Foi também a maior e mais universal das conferências até então promovidas pelas Nações Unidas, com 178 estados representados nas negociações e 118 chefes de Estado participando da "Cúpula da Terra".

Construída sobre as premissas de Estocolmo, a Conferência das Nações Unidas sobre Meio Ambiente e Desenvolvimento (UNCED) ou Cúpula da Terra foi convocada com o propósito de discutir problemas urgentes referentes à proteção ambiental e ao desenvolvimento socioeconômico. Os líderes governamentais então reunidos assinaram a Convenção sobre o Clima e a Convenção sobre a Biodiversidade, endossaram a Declaração do Rio de Janeiro sobre Meio Ambiente e Desenvolvimento e a Declaração de Princípios sobre Florestas e adotaram a Agenda 21, um plano de ação analítico com cerca de 500 páginas para a realização do desenvolvimento sustentável no século XXI.

Durante a Cúpula da Terra foi proposta a criação de um órgão especializado, destinado a facilitar os acordos intergovernamentais sobre mudança climática, biodiversidade, Princípios das Florestas, Declaração do Rio (Declaração de Meio Ambiente e Desenvolvimento) implementação da Agenda 21.

Os capítulos 29 e 30 da Agenda 21 abordam especificamente o papel dos trabalhadores, sindicatos e empresas. De acordo com 0 site http://www.observatoriosocial.org.br, os sindicatos são considerados atores importantes pela sua preocupação com a proteção do ambiente de trabalho, com o meio ambiente 
Revista Eletrônica de Ciência Administrativa (RECADM) - ISSN 1677-7387

Faculdade Cenecista de Campo Largo - Coordenação do Curso de Administração v. 4, n. 1, maio/2005 - http://revistas.facecla.com.br/index.php/recadm/

externo e com o desenvolvimento econômico e socialmente responsável. Conforme esta visão, os trabalhadores e seus representantes deveriam participar plenamente da implementação e avaliação das atividades relacionadas com a Agenda 21, trabalhando para:

$\rightarrow$ Promover a ratificação das convenções pertinentes à OIT.

$\rightarrow$ Estabelecer mecanismos bipartidos e tripartites sobre segurança, saúde e desenvolvimento sustentável.

$\rightarrow$ Aumentar o número de acordos ambientais coletivos voltados para o desenvolvimento sustentável.

$\rightarrow$ Reduzir os acidentes, ferimentos e moléstias de trabalho.

$\rightarrow$ Aumentar a oferta de educação, treinamento e atualização para os trabalhadores, em particular na área de saúde e segurança no trabalho e do meio ambiente.

$\rightarrow$ Promover a liberdade de associação (liberdade sindical).

A Agenda 21 propõe dois programas para o comércio e a indústria: Promoção de uma produção mais limpa e Promoção da responsabilidade empresarial. Os objetivos do programa voltado para a responsabilidade empresarial são: estimular o conceito de vigilância no manejo e utilização dos recursos naturais pelos empresários, aumentar o número de empresários cujas empresas apóiem e implementem políticas de desenvolvimento sustentável.

\section{6 - Pacto Global}

O secretário-geral das Nações Unidas, Kofi Annan, propôs primeiramente o Pacto Global no Fórum Econômico Mundial realizado em Davos em 31 de janeiro de 1999. Em meio a um cenário de crescente preocupação sobre os efeitos da globalização, o secretário-geral convocou lideranças empresarias a se unirem a uma iniciativa internacional, o Pacto Global, que aproximaria as empresas das agências das Nações Unidas, organizações do trabalho, organizações não governamentais e outros atores da sociedade civil para a promoção de ações e parcerias na busca de uma visão desafiadora: uma economia global mais sustentável e inclusiva.

Segundo o site http://www.pactoglobal.org.br, Annan entendeu que enquanto a cidadania empresarial, também denominada de "responsabilidade empresarial", "desenvolvimento sustentável" e "resultado triplo", entre outros termos, estava emergindo como uma tendência no mundo dos negócios, não existia estrutura internacional para assistir as empresas no desenvolvimento e na promoção da gestão global com base em valores. Mediante a consolidação do Pacto Global em princípios aceitos internacionalmente, os participantes poderiam se sentir seguros de que suas ações estariam sendo guiadas por valores universalmente sustentados e endossados. 
Revista Eletrônica de Ciência Administrativa (RECADM) - ISSN 1677-7387 Faculdade Cenecista de Campo Largo - Coordenação do Curso de Administração v. 4, n. 1, maio/2005 - http://revistas.facecla.com.br/index.php/recadm/

A partir do lançamento em 26 de julho de 2000, centenas de empresas e de organizações se engajaram na iniciativa. As agências das Nações Unidas envolvidas com o Pacto Global são o Alto Comissariado para Direitos Humanos, Programa das Nações Unidas para o Meio Ambiente (PNUMA), Organização Internacional do Trabalho (OIT), Organização das Nações Unidas para o Desenvolvimento Industrial (Unido) e o Programa das Nações Unidas para o Desenvolvimento (PNUD).

O Pacto Global se baseia em nove princípios com abrangência nas áreas de direitos humanos, direitos do trabalho e proteção ambiental, conforme a figura 3. Estes princípios são derivados da Declaração Universal de Direitos Humanos, Declaração da Organização Internacional de Trabalho sobre os Princípios Fundamentais e Direitos no Trabalho e Declaração do Rio sobre Meio Ambiente e Desenvolvimento.

Figura 3 - Abrangência das áreas

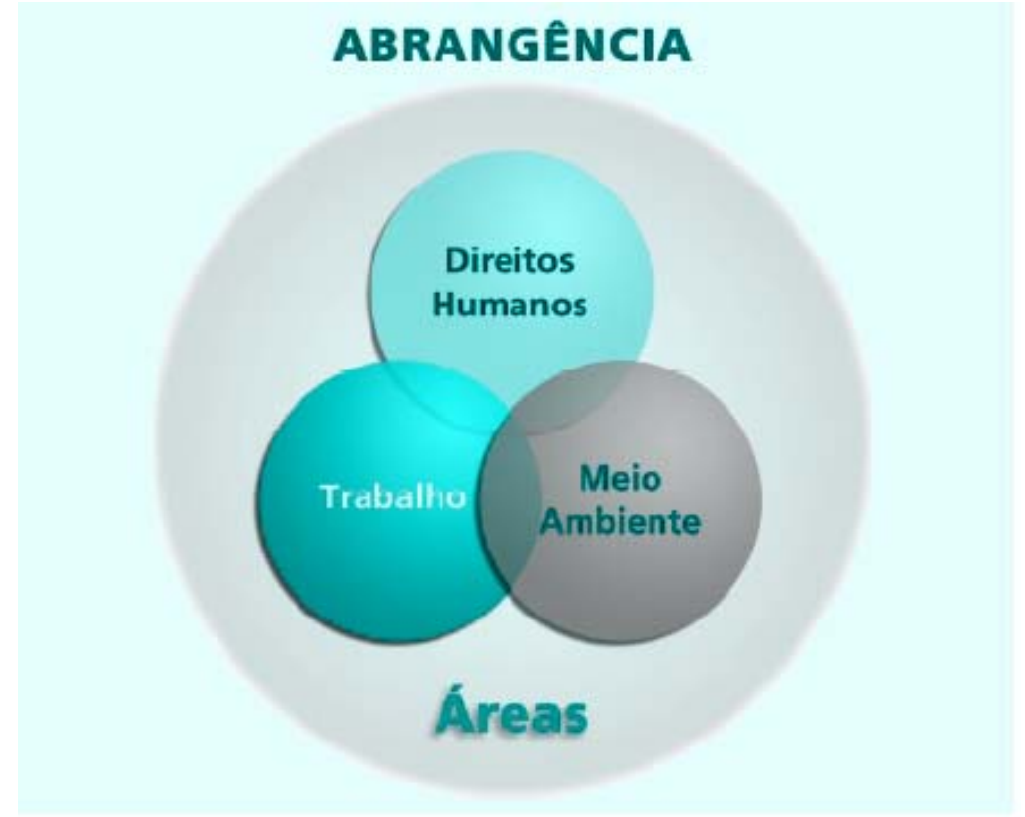

Fonte: http:// www.ethos.org.br/ Uniethos (2004)

O Pacto Global solicita que as empresas integrem estes princípios em suas principais operações e adotem projetos e atividades empresariais que favoreçam os princípios e ampliem os objetivos das Nações Unidas. O objetivo é estabelecer um compromisso das empresas líderes mundiais na construção dos pilares sociais e ambientas da nova economia, em benefício de toda população mundial.

Quanto aos projetos, o Pacto Global está encorajando iniciativas e programas com ênfase no cumprimento dos oito objetivos de desenvolvimento do milênio das Nações Unidas, apresentados no quadro 3.

Quadro 3 - Objetivos de desenvolvimento do milênio das Nações Unidas 
Revista Eletrônica de Ciência Administrativa (RECADM) - ISSN 1677-7387

Faculdade Cenecista de Campo Largo - Coordenação do Curso de Administração v. 4, n. 1, maio/2005 - http://revistas.facecla.com.br/index.php/recadm/

\begin{tabular}{|c|c|}
\hline $\begin{array}{l}\text { Erradicar a pobreza extrema } \\
\text { e a fome }\end{array}$ & $\begin{array}{l}\rightarrow \text { Reduzir pela metade a proporção de pessoas que } \\
\text { vivem com menos de um dólar por dia } \\
\rightarrow \text { Reduzir pela metade a proporção de pessoas que } \\
\text { sofrem de fome }\end{array}$ \\
\hline $\begin{array}{l}\text { Atingir a educação básica } \\
\text { universal }\end{array}$ & $\begin{array}{l}\rightarrow \text { Assegurar que todos os meninos e meninas } \\
\text { concluam o curso completo da escola fundamental }\end{array}$ \\
\hline $\begin{array}{l}\text { Promover a igualdade de } \\
\text { gênero e o empoderamento } \\
\text { das mulheres }\end{array}$ & $\begin{array}{l}\rightarrow \text { Eliminar a disparidade de gênero na educação } \\
\text { fundamental e na secundária, preferencialmente até } \\
\text { 2005, e em todos os níveis até } 2015\end{array}$ \\
\hline $\begin{array}{l}\text { Reduzir a mortalidade } \\
\text { infantil }\end{array}$ & $\begin{array}{l}\rightarrow \text { Reduzir em até dois terços o índice de mortalidade } \\
\text { entre as crianças com menos de cinco anos }\end{array}$ \\
\hline úde materna & $\begin{array}{l}\rightarrow \text { Reduzir em até três quartos o índice de } \\
\text { mortalidade das mães }\end{array}$ \\
\hline $\begin{array}{l}\text { Combater o HIVIAIDS, a } \\
\text { malária e outras doenças }\end{array}$ & $\begin{array}{l}\rightarrow \text { Parar e começar a reverter o crescimento do } \\
\text { HIVIAIDS } \\
\rightarrow \text { Parar e começar a reverter a incidência da malária } \\
\text { e de outras doenças importantes }\end{array}$ \\
\hline $\begin{array}{l}\text { Assegurar a } \\
\text { sustentabilidade ambiental }\end{array}$ & $\begin{array}{l}\rightarrow \text { Integrar os princípios de desenvolvimento } \\
\text { sustentável em políticas e programas nacionais; } \\
\text { reverter a perda de recursos ambientais } \\
\rightarrow \text { Reduzir pela metade a proporção de pessoas } \\
\text { sem acesso sustentável à água potável } \\
\rightarrow \text { Alcançar uma melhoria significativa nas vidas de } \\
\text { pelo menos } 100 \text { milhões de moradores de favelas até } \\
2020\end{array}$ \\
\hline $\begin{array}{l}\text { Desenvolver uma parceria } \\
\text { global para o } \\
\text { desenvolvimento }\end{array}$ & $\begin{array}{l}\rightarrow \text { Desenvolver ainda um sistema comercial e } \\
\text { financeiro aberto com base em normas, previsível e } \\
\text { não discriminatório. } \\
\rightarrow \text { Incluir um compromisso para uma boa } \\
\text { governança, desenvolvimento e redução da pobreza } \\
\text { - nacional e internacionalmente } \\
\rightarrow \text { Tratar das necessidades especiais dos países } \\
\text { menos desenvolvidos. Isto inclui o acesso à isenção } \\
\text { de tarifas e quotas em suas exportações; aumentar o } \\
\text { perdão da dívida para os países pobres com dívida } \\
\text { substancial; cancelamento da dívida bilateral oficial e } \\
\text { assistência oficial mais generosa para o } \\
\text { desenvolvimento de países comprometidos com a }\end{array}$ \\
\hline
\end{tabular}


Revista Eletrônica de Ciência Administrativa (RECADM) - ISSN 1677-7387 Faculdade Cenecista de Campo Largo - Coordenação do Curso de Administração v. 4, n. 1, maio/2005 - http://revistas.facecla.com.br/index.php/recadm/

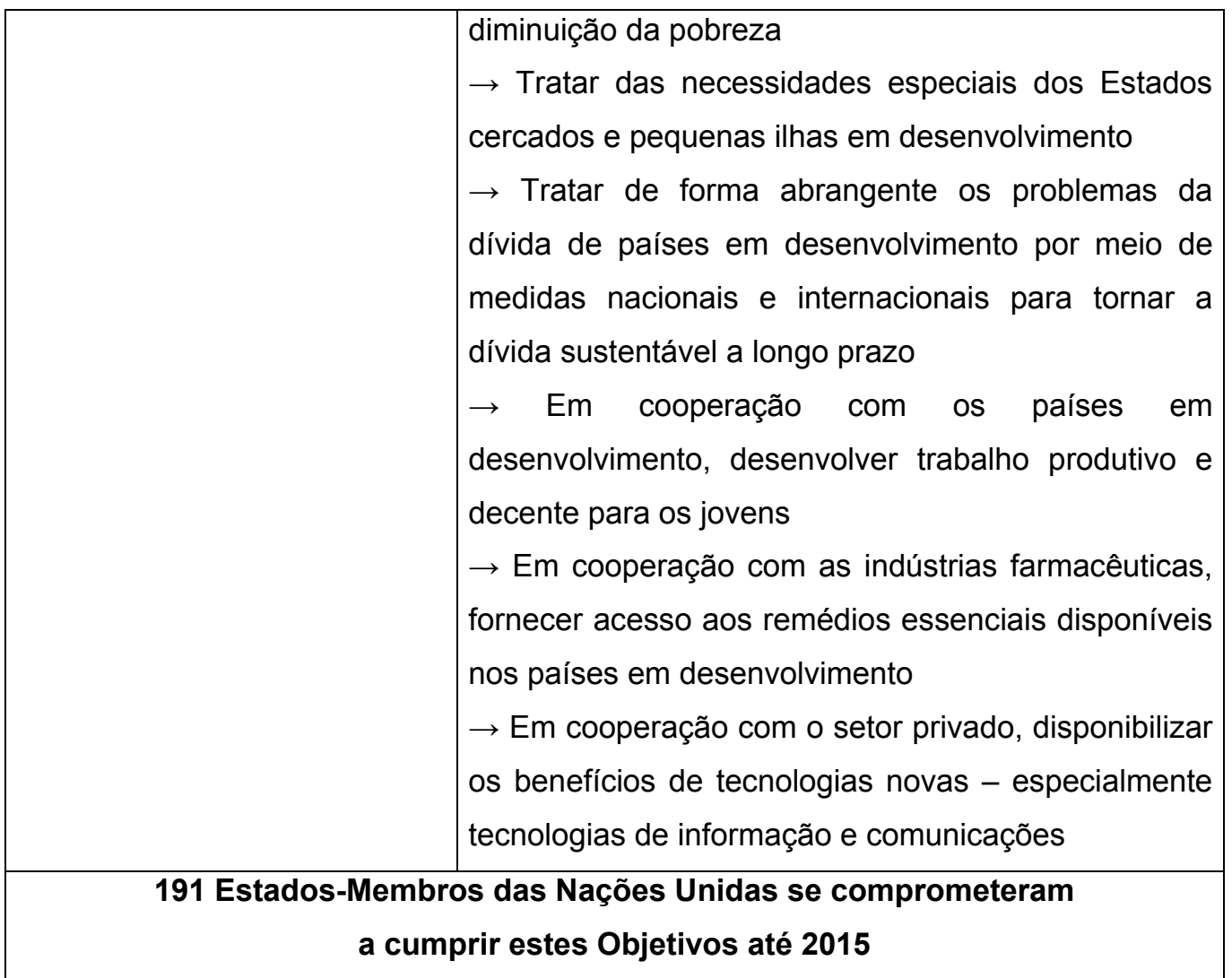

Fonte: http://www.pactoglobal.org.br/ (2004)

Há inúmeros benefícios na participação das empresas no Pacto Global, tais como:

$\rightarrow$ Produzir soluções práticas para os problemas contemporâneos relacionados à globalização, desenvolvimento sustentado e responsabilidade empresarial, em um contexto de múltiplos stakeholders.

$\rightarrow$ Colaborar com os princípios universais e a cidadania empresarial responsável, tornando a economia global mais sustentável e inclusiva.

$\rightarrow$ Alavancar o poder de alcance e reunião global das Nações Unidas junto a governos, empresas, sociedade civil e outros stakeholders.

$\rightarrow$ Compartilhar boas práticas e aprendizados.

Os componentes do Pacto Global estão descriminados no quadro 4. 
Revista Eletrônica de Ciência Administrativa (RECADM) - ISSN 1677-7387

Faculdade Cenecista de Campo Largo - Coordenação do Curso de Administração v. 4 , n. 1, maio/2005 - http://revistas.facecla.com.br/index.php/recadm/

\section{Quadro 4 - Os quatro componentes do Pacto Global}

\begin{tabular}{|c|c|}
\hline Fóruns de Aprendizagem & Diálogos de Políticas \\
\hline $\begin{array}{l}\text { Objetivos } \\
\rightarrow \text { promover uma base de conhecimentos } \\
\text { para aprender como as empresas estão } \\
\text { implementando os princípios universais das } \\
\text { Nações Unidas } \\
\rightarrow \text { criar uma plataforma para motivar as } \\
\text { empresas a tomarem medidas mediante a } \\
\text { implementação dos princípios do Pacto } \\
\text { Global } \\
\rightarrow \text { reforçar mutuamente os Diálogos da } \\
\text { Política }\end{array}$ & $\begin{array}{l}\text { Objetivos } \\
\rightarrow \text { promover uma troca de opiniões e um } \\
\text { discussão permanente sobre os desafios } \\
\text { contemporâneos da globalização } \\
\rightarrow \text { encorajar as redes de ação entre as } \\
\text { organizações trabalhistas e as organizações da } \\
\text { sociedade civil } \\
\rightarrow \text { desenvolver confiança e colaboração } \\
\rightarrow \text { desenvolver soluções inovadoras para } \\
\text { problemas complexos }\end{array}$ \\
\hline $\begin{array}{l}\text { Atividades } \\
\rightarrow \text { os Fóruns de Aprendizagem concluíram } \\
\text { sua fase piloto em outubro de } 2001 \text { após a } \\
\text { apresentação de } 44 \text { casos para estudo } \\
\text { pelas empresas } \\
\rightarrow \text { subseqüentemente, o fórum adotou uma } \\
\text { dupla abordagem para apresentações que } \\
\text { adota "exemplos" do trabalho da empresa } \\
\text { colocados no website do Pacto, junto a } \\
\text { estudos detalhados de casos selecionados } \\
\rightarrow \text { os participantes são convidados para } \\
\text { uma reunião anual para dividir experiências } \\
\text { de trabalho com o Pacto Global }\end{array}$ & $\begin{array}{l}\text { Atividades } \\
\rightarrow \text { os diálogos em } 2001 \text { exploravam o papel de } \\
\text { "O Setor Privado nas Zonas de Conflito" } \\
\rightarrow \text { os diálogos em } 2002 \text { concentraram-se em } \\
\text { "Negócio e Desenvolvimento Sustentável" }\end{array}$ \\
\hline
\end{tabular}

\begin{tabular}{|c|c|}
\hline Projetos em Parceria & Redes Locais \\
\hline $\begin{array}{l}\text { Objetivos } \\
\rightarrow \text { promover iniciativas em parceria para } \\
\text { desenvolver os nove princípios principais e } \\
\text { outros objetivos das Nações Unidas, tais } \\
\text { como as Metas de Desenvolvimento do } \\
\text { Millennium } \\
\rightarrow \text { estender os benefícios da globalização } \\
\text { através de uma abordagem de parceria } \\
\rightarrow \text { promover o progresso global e a } \\
\text { estabilidade }\end{array}$ & $\begin{array}{l}\text { Objetivos } \\
\rightarrow \text { desenvolver o Pacto Global para uma } \\
\text { verdadeira iniciativa global } \\
\rightarrow \text { facilitar o estabelecimento de redes nacionais } \\
\text { e regionais que trabalham com questões do } \\
\text { Pacto Global } \\
\rightarrow \text { desenvolver conexões entre os empregados } \\
\text { comuns e as atividades globais sobre os } \\
\text { princípios do Pacto Global }\end{array}$ \\
\hline $\begin{array}{l}\text { Atividades } \\
\rightarrow \text { a iniciativa da diversidade - a } \\
\text { Discriminação é Assunto de Todos - envolve } \\
\text { seis empresas que desenvolvem parcerias a } \\
\text { longo prazo para promover a boa prática no } \\
\text { local de trabalho } \\
\rightarrow \text { outros exemplos de projetos até esta data } \\
\text { incluem empresas que trabalham com } \\
\text { outras organizações no desenvolvimento de } \\
\text { acordos trabalhistas, a prestação de } \\
\text { assistência médica e a redução de emissões } \\
\text { de dióxido de carbono }\end{array}$ & $\begin{array}{l}\text { Atividades } \\
\rightarrow \text { atividades extensivas que incluem workshops } \\
\text { para líderes empresariais em níveis nacional e } \\
\text { regional } \\
\rightarrow \text { nas reuniões de } 2001 \text { e } 2002 \text { ocorreram } \\
\text { reuniões no mundo inteiro com líderes } \\
\text { empresariais, organizações trabalhistas e grupos } \\
\text { da sociedade civil que se reúnem para discutir } \\
\text { como levar adiante o Pacto Global em suas } \\
\text { regiões } \\
\rightarrow \text { Melbourne (Austrália) tornou-se em } 2001 \text { a } \\
\text { primeira cidade a se engajar no Pacto Global }\end{array}$ \\
\hline
\end{tabular}

Fonte: http://www.pactoglobal.org.br/ (2004)

Os princípios universais do Pacto Global são:

\section{$\rightarrow$ Princípios de Direitos Humanos}

1. Respeitar e proteger os direitos humanos. 
Revista Eletrônica de Ciência Administrativa (RECADM) - ISSN 1677-7387

Faculdade Cenecista de Campo Largo - Coordenação do Curso de Administração v. 4, n. 1, maio/2005 - http://revistas.facecla.com.br/index.php/recadm/

2. Impedir violações de direitos humanos.

$\rightarrow$ Princípios de Direitos do Trabalho

3 - Apoiar a liberdade de associação no trabalho.

4 - Abolir o trabalho forçado.

5 - Abolir o trabalho infantil.

6 - Eliminar a discriminação no ambiente de trabalho.

$\rightarrow$ Princípios de Proteção Ambiental

7 - Apoiar uma abordagem preventiva aos desafios ambientais.

8 - Promover a responsabilidade ambiental.

9 - Encorajar tecnologias que não agridem o meio ambiente.

A origem dos Princípios 1 e 2, relacionados aos direitos humanos, é encontrada na Declaração Universal dos Direitos Humanos (DUDH) de 1948. O objetivo desta Declaração é estipular padrões internacionais mínimos para a proteção dos direitos e liberdades dos indivíduos, hoje amplamente considerados como formadoras da base do direito internacional. Especificamente, os componentes da DUDH são considerados como lei consuetudinária internacional e não exigem assinatura ou aprovação pelo Estado para serem reconhecidos como padrão legal.

Baseando-se no fato da responsabilidade recair sobre cada indivíduo e cada grupo em sociedade é que os Princípios 1 e 2 do Pacto Global convocam as empresas não somente a desenvolver uma consciência dos direitos humanos, mas também a trabalhar dentro de sua esfera de influência para proteger estes direitos humanos universais.

Os quatro princípios de direitos do trabalho do Pacto Global, propugnados pela Organização Internacional de Trabalho (OIT) por meio da Declaração dos Princípios Fundamentais e Direitos no Trabalho, foram adotados na $86^{\text {a }}$ Conferência Internacional do Trabalho em 1998. A OIT tem uma estrutura única (tripartite) composta de governos, empregadores e trabalhadores, sendo a única agência das Nações Unidas cujos membros são compostos por governos e setor privado. Conseqüentemente, a Declaração representa um consenso universal entre aqueles partícipes preocupados com as questões trabalhistas, de promoção e proteção dos princípios no mundo inteiro.

O objetivo da OIT, ao participar do Pacto Global, é catalisar o apoio da comunidade empresarial. Os princípios dos Direitos do Trabalho 3, 4, 5 e 6 tratam dos princípios fundamentais no local de trabalho e o desafio empresarial é adotar estes valores aceitos universalmente e aplicá-los na empresa.

A Declaração do Rio sobre Meio Ambiente e Desenvolvimento oferece a base para os Princípios Ambientais de $n^{\circ} 7,8$ e 9 do Pacto Global.

O negócio ganha legitimidade através do atendimento das necessidades da sociedade e cada vez mais a sociedade está expressando a clara necessidade de mais 
Revista Eletrônica de Ciência Administrativa (RECADM) - ISSN 1677-7387

Faculdade Cenecista de Campo Largo - Coordenação do Curso de Administração v. 4, n. 1, maio/2005 - http://revistas.facecla.com.br/index.php/recadm/

práticas sustentáveis ambientalmente. Um modo de a empresa demonstrar o seu compromisso com uma maior responsabilidade ambiental é através da mudança do seu modus operandi dos chamados "métodos tradicionais" para abordagens mais responsáveis, tratando de questões ambientais:

\begin{tabular}{|l|l|}
\hline \multicolumn{1}{|c|}{ De } & \multicolumn{1}{c|}{ Para } \\
\hline Uso de recursos ineficazes & Produtividade de recursos \\
\hline Tecnologia end-of-pipe & Produção mais limpa \\
\hline Relações públicas & Controle corporativo \\
\hline Reativo & Pró-ativo \\
\hline Sistemas de administração & Ciclos da vida, projeto de negócio \\
\hline Comunicação unilateral e passiva & $\begin{array}{l}\text { Multiplicidade de participantes, diálogo } \\
\text { ativo }\end{array}$ \\
\hline
\end{tabular}

Fonte: http://www.pactoglobal.org.br.

As razões pelas quais uma empresa deve pensar sobre a melhoria de seu desempenho ambiental são:

$\rightarrow$ Aplicação de uma produção mais limpa e uma eficiência ecológica levam a uma melhor produtividade dos recursos.

$\rightarrow$ Novos instrumentos econômicos (impostos, encargos, alvarás comerciais) estão recompensando as empresas limpas.

$\rightarrow$ Os regulamentos ambientais estão endurecendo.

$\rightarrow$ As seguradoras preferem uma empresa mais limpa e de risco mais baixo.

$\rightarrow$ Os bancos tendem mais a emprestar para uma empresa cujas operações não onerarão o banco com processos na área ambiental ou grandes contas de liquidação.

$\rightarrow A$ administração ambiental tem um efeito positivo para a imagem da empresa.

$\rightarrow$ Os empregados tendem a preferir trabalhar para uma empresa ambientalmente responsável (tal empresa também tem geralmente registros de boa saúde e segurança para o trabalhador).

$\rightarrow$ A poluição ambiental ameaça a saúde humana.

$\rightarrow$ Os clientes estão exigindo produtos mais limpos.

\section{7 - O Livro Branco de Responsabilidade Ambiental da Comissão Européia}

O livro branco sobre a responsabilidade ambiental, publicado em fevereiro de 2000, tinha por objetivo analisar o modo como o princípio do poluidor-pagador poderia ser concretizado de forma a realizar a política ambiental da Comunidade. No final dessa análise, a elaboração de uma diretriz, em julho de 2002, surgiu como o melhor meio para instaurar um regime comunitário de responsabilidade ambiental. Intitulado de "Comunicação da Comissão relativa à responsabilidade social das empresas: um contributo das empresas para o desenvolvimento sustentável", a proposta de diretrizes é o resultado da reflexão efetuada na seqüência do Livro Branco e por ocasião da qual se procedeu a uma consulta pública. 
Revista Eletrônica de Ciência Administrativa (RECADM) - ISSN 1677-7387 Faculdade Cenecista de Campo Largo - Coordenação do Curso de Administração v. 4, n. 1, maio/2005 - http://revistas.facecla.com.br/index.php/recadm/

Nos termos desta proposta, os danos ambientais são definidos por referência ao meio aquático coberto pela legislação comunitária em matéria de gestão das águas, às espécies e habitats protegidos pela legislação comunitária relativa à conservação da natureza, às zonas protegidas pela legislação nacional ou regional em matéria de conservação da natureza, assim como por referência aos perigos para a saúde derivados da contaminação dos solos.

Esta proposta de diretiva se aplica aos danos ambientais e às correspondentes ameaças iminentes no caso de tais danos ocorrerem em conseqüência das atividades profissionais enunciadas no anexo I do livro. Os danos graves que prejudiquem a biodiversidade e que resultem de atividades profissionais não enunciadas no anexo I do livro são igualmente contemplados pela proposta. Excluem-se os danos causados por conflitos armados, por catástrofes naturais, por ocorrências autorizadas ou por atividades isentas de riscos segundo os conhecimentos científicos do momento.

Quando surge uma ameaça iminente de dano ambiental, a autoridade competente designada por cada Estado-Membro obriga o operador (poluidor potencial) a tomar as medidas preventivas adequadas ou toma-as ela própria, cobrando em seguida os encargos a elas associados.

Quando se produz um dano, a autoridade competente obriga o operador em causa a tomar as medidas de reparação adequadas (determinadas com base nas regras e nos princípios enunciados no anexo II da proposta) ou toma-as ela própria, cobrando em seguida os encargos. Se se tiverem produzido diversos danos, a autoridade competente pode decidir a ordem de prioridade na sua reparação.

Se o operador não tiver possibilidade financeira de tomar a totalidade ou uma parte das medidas de reparação necessárias ou se a identificação do poluidor responsável se verificar impossível, os Estados-Membros velam, em qualquer caso, para que as medidas sejam tomadas. Conforme o caso, instituem mecanismos de financiamento alternativo (como garantias financeiras, cauções, fundos coletivos).

$\mathrm{Na}$ hipótese de a autoridade competente ter aplicado medidas de prevenção ou reparação, esta cobrará, do operador responsável pelo dano ou pela ameaça iminente de dano, os custos que suportou. O mesmo princípio se aplica relativamente às avaliações ambientais realizadas com a finalidade de determinar a extensão do dano e as medidas a tomar para o reparar. A autoridade competente deve desencadear os procedimentos de cobrança no prazo de cinco anos a contar da data de aplicação das medidas de prevenção ou reparação.

Se for causado dano à biodiversidade por atividades profissionais não enunciadas no anexo I sem dolo ou negligência do operador, este não terá de suportar os custos das medidas de prevenção ou reparação. Se houver dolo ou negligência do operador, aplicar-se-á o princípio do poluidor-pagador. 
Revista Eletrônica de Ciência Administrativa (RECADM) - ISSN 1677-7387 Faculdade Cenecista de Campo Largo - Coordenação do Curso de Administração v. 4, n. 1, maio/2005 - http://revistas.facecla.com.br/index.php/recadm/

Se vários operadores forem co-responsáveis por um dano, deverão suportar os custos associados à reparação, quer solidariamente, quer numa base proporcional. Posto isto, o operador capaz de determinar a sua parte de responsabilidade só é obrigado a pagar na proporção dessa parte.

As pessoas singulares ou coletivas que possam ser afetadas negativamente por um dano ambiental ou as entidades qualificadas (organismos habilitados a agir no interesse do ambiente, incluindo organizações cujo fim é a proteção do ambiente) podem requerer às autoridades competentes que intervenham perante um dano. No prazo de quatro meses após ter sido solicitada, a autoridade competente informa a pessoa ou entidade requerente da sua decisão de agir ou não e das suas razões. As pessoas e entidades que introduzam pedidos de intervenção podem apresentar recurso a um tribunal ou organismo ad hoc, com vista a fazer apreciar a legalidade das decisões, ações ou inações da autoridade competente.

Se um dano ou uma ameaça de dano puder ter conseqüências que afetem mais de um Estado-Membro, estes cooperarão na ação de prevenção ou reparação.

No prazo de cinco anos após a entrada em vigor da diretiva, os EstadosMembros apresentarão um relatório sobre a sua aplicação à Comissão que, por sua vez, apresentará um relatório ao Parlamento Europeu e ao Conselho com base nos relatórios nacionais, acompanhado, se necessário, de propostas pertinentes.

O Livro Branco traz as seguintes definições sobre responsabilidade social corporativa:

$\rightarrow$ É um comportamento que as empresas adotam voluntariamente e para além de prescrições legais, porque consideram ser do seu interesse a longo prazo.

$\rightarrow$ Está estreitamente associada ao conceito de desenvolvimento sustentável: as empresas têm de integrar nas suas operações o impacto econômico, social e ambiental.

$\rightarrow$ Não é um "acréscimo" opcional às atividades nucleares de uma empresa, mas sim à forma como esta é gerida.

\section{8 - O Livro Verde da Comissão Européia}

O Livro Verde da Comissão Européia tem como objetivo promover um quadro europeu para a responsabilidade social das empresas e foi publicado em julho de 2001. Estabelece as diretrizes básicas de responsabilidade social e ambiental para as empresas européias.

Visa lançar um amplo debate quanto às formas de promoção pela União Européia da responsabilidade social das empresas tanto a nível europeu como internacional e, mais especificamente, quanto às possibilidades de explorar ao máximo as experiências existentes, incentivar o desenvolvimento de práticas inovadoras, aumentar a transparência, bem como a fiabilidade da avaliação e da validação. 
Revista Eletrônica de Ciência Administrativa (RECADM) - ISSN 1677-7387

Faculdade Cenecista de Campo Largo - Coordenação do Curso de Administração v. 4, n. 1, maio/2005 - http://revistas.facecla.com.br/index.php/recadm/

Preconiza ainda uma abordagem baseada em parcerias mais estreitas, de modo a que todas as partes interessadas desempenhem um papel ativo.

São vários os fatores que motivam esta evolução para a responsabilidade social pelas empresas:

$\rightarrow$. novas preocupações e expectativas dos cidadãos, consumidores, autoridades públicas e investidores num contexto de globalização e de mutação industrial em larga escala,

$\rightarrow$ critérios sociais que possuem uma influência crescente sobre as decisões individuais ou institucionais de investimento, tanto na qualidade de consumidores como de investidores,

$\rightarrow$. a preocupação crescente face aos danos provocados no meio ambiente pelas atividades econômicas,

$\rightarrow$. a transparência gerada nas atividades empresariais pelos meios de comunicação social e pelas modernas tecnologias da informação e da comunicação.

O Livro Verde define responsabilidade social corporativa como "a integração voluntária de preocupações sociais e ambientais por parte das empresas nas suas operações e na sua interação com outras partes interessadas", conscientes que estão de que um comportamento responsável é fonte de êxitos comerciais duradouros. A responsabilidade social das empresas (SER) implica igualmente a gestão da mudança de forma socialmente responsável, com as empresas a procurar compromissos equilibrados e aceitáveis por todas as partes entre as exigências e as necessidades dos vários agentes envolvidos. Caso se revelem capazes de gerir a mudança de forma socialmente responsável, as empresas acusarão efeitos positivos ao nível macroeconômico.

Este debate está também ligado à reflexão conduzida pela Comissão sobre o Livro Branco relativo à governança na União Européia, porquanto a responsabilidade social das empresas pode contribuir significativamente para a criação de um clima favorável ao espírito empresarial e se articular ainda com outro objetivo da Comissão: criar uma Europa aberta, inovadora e empreendedora - a Enterprise Europe.

A responsabilidade social das empresas tem grandes implicações para todos os agentes econômicos e sociais, bem como para as autoridades públicas que deverão considerá-las ao definirem as suas próprias ações.

Vários Estados-Membros reconheceram a importância dela e tomaram medidas ativas para a sua promoção. Uma vez que enfrentam desafios semelhantes, os Estados-Membros poderão retirar ensinamentos no intercâmbio das respectivas experiências. Em termos globais, a Comissão poderá promover a responsabilidade social das empresas através dos seus programas e atividades. Além disso, importa garantir a 
Revista Eletrônica de Ciência Administrativa (RECADM) - ISSN 1677-7387

Faculdade Cenecista de Campo Largo - Coordenação do Curso de Administração v. 4, n. 1, maio/2005 - http://revistas.facecla.com.br/index.php/recadm/

coerência e a conformidade das abordagens à responsabilidade social das empresas com as políticas comunitárias e as obrigações internacionais.

O Livro Verde divide as áreas de conteúdo da responsabilidade social corporativa em dois grandes blocos, sendo que o primeiro é relativo a aspectos internos e o segundo a aspectos externos.

$\mathrm{Na}$ dimensão interna, ao nível da empresa, as práticas socialmente responsáveis implicam, fundamentalmente, os trabalhadores e se prendem em questões como o investimento no capital humano, na saúde, na segurança e na gestão da mudança, enquanto as práticas ambientalmente responsáveis se relacionam sobretudo com a gestão dos recursos naturais explorados no processo de produção. Estes aspectos possibilitam a gestão da mudança e a conciliação do desenvolvimento social com uma competitividade reforçada.

Quanto à dimensão externa, a responsabilidade social de uma empresa ultrapassa a esfera da própria empresa e se estende à comunidade local, envolvendo, para além dos trabalhadores e acionistas, um vasto espectro de outras partes interessadas: parceiros comerciais e fornecedores, clientes, autoridades públicas e ONGs que exercem a sua atividade junto das comunidades locais ou no domínio do ambiente.

\section{9 - A comunicação da Comissão da União Européia a respeito da responsabilidade social das empresas}

Esta comunicação é relativa à responsabilidade social das empresas (uma contribuição empresarial ao desenvolvimento sustentável de 02 de julho de 2002) que estabelece a estratégia de promoção da responsabilidade social sobre a base das consultas do Livro Verde.

Em julho de 2001, a Comissão apresentou um Livro Verde intitulado "Promover um quadro europeu para a responsabilidade social das empresas". Este documento se destinava, primeiramente, a lançar um debate sobre o conceito de responsabilidade social das empresas e, em segundo lugar, a identificar formas de criar uma parceria que permita o desenvolvimento de um quadro europeu para a promoção deste conceito.

A responsabilidade social corporativa pode, por conseguinte, ajudar à realização do objetivo estratégico da União Européia de, até 2010, se tornar "a economia baseada no conhecimento mais dinâmica e competitiva do mundo, capaz de garantir um crescimento econômico sustentável, com mais e melhores empregos, e com maior coesão social".

O processo de consulta sobre o Livro Verde veio confirmar a necessidade de ação comunitária no domínio da responsabilidade social das empresas. Nesta 
Revista Eletrônica de Ciência Administrativa (RECADM) - ISSN 1677-7387 Faculdade Cenecista de Campo Largo - Coordenação do Curso de Administração v. 4, n. 1, maio/2005 - http://revistas.facecla.com.br/index.php/recadm/

Comunicação, que dá seguimento ao Livro Verde, a Comissão apresenta a estratégia da UE para promover a RSE. As principais conclusões dos diferentes atores são:

$\rightarrow$ As empresas sublinham a natureza voluntária da RSE, a sua integração no contexto do desenvolvimento sustentável e a necessidade de aprofundar o seu conteúdo a nível global. Salientam ainda o fato de não se poderem esperar soluções "universais que sirvam a todos". No seu ponto de vista, eventuais tentativas de regulamentar a RSE no âmbito da UE se revelariam contraproducentes, na medida em que iriam sufocar a criatividade e a inovação de empresas que constituem o motor de um desenvolvimento bem sucedido do conceito, podendo induzir conflitos de prioridades para empresas que operam em diferentes áreas geográficas.

$\rightarrow$ Os sindicatos e as organizações da sociedade civil sublinham que o caráter voluntário das iniciativas não é suficiente para salvaguardar os direitos dos trabalhadores e dos cidadãos. Defendem a definição de um enquadramento regulamentar que estabeleça normas mínimas e assegure uma envolvente equilibrada. Insistem também que, para serem credíveis, as práticas de RSE não poderão ser desenvolvidas, implementadas e avaliadas unilateralmente pelas empresas, devendo sim contar com o envolvimento das partes interessadas. Solicitam igualmente a instauração de mecanismos eficazes para assegurar a responsabilização das empresas pelo impacto social e ambiental das suas atividades.

$\rightarrow$ Os investidores invocam a necessidade de melhorar os métodos de divulgação de informações e a transparência das práticas das empresas, a metodologia utilizada pelas empresas de "rating" e a gestão de fundos de ISR (investimento socialmente responsável) e dos fundos de pensão.

$\rightarrow$ As organizações de consumidores sublinham a importância de uma informação exaustiva e fiável sobre as condições éticas, sociais e ambientais de produção e comercialização de produtos e serviços para orientarem as suas opções de compra.

$\rightarrow$ Na sua Resolução de 3 de dezembro de 2001, o Conselho chama a atenção para o fato de uma abordagem européia da responsabilidade social das empresas poder contribuir para o desenvolvimento do conceito, ao completar as medidas existentes aos níveis local e nacional, acrescentando-lhes mais-valia. Menciona ainda que a responsabilidade social das empresas poderá contribuir não só para a promoção de um nível elevado de coesão social, de proteção do ambiente e de respeito pelos direitos fundamentais, mas também para o reforço da competitividade em todos os sectores de atividade e em todos os tipos de empresas, das PME às multinacionais.

$\rightarrow$. O Comitê Econômico e Social sublinha que os princípios de ação voluntária e de sustentabilidade ambiental, econômica e social, junto das orientações consubstanciadas em acordos de organizações internacionais atualmente em vigor, deverão constituir o 
Revista Eletrônica de Ciência Administrativa (RECADM) - ISSN 1677-7387

Faculdade Cenecista de Campo Largo - Coordenação do Curso de Administração v. 4, n. 1, maio/2005 - http://revistas.facecla.com.br/index.php/recadm/

enquadramento de referência para iniciativas européias ulteriores de apoio aos esforços envidados pelas empresas no domínio da responsabilidade social.

$\rightarrow$ O Comitê das Regiões considera haver espaço para uma ação a nível europeu no sentido de providenciar um quadro para sensibilizar, promover princípios responsáveis e assistir as empresas e as autoridades públicas na integração da RSE nas respectivas atividades.

$\rightarrow$ O Parlamento Europeu propõe integrar a responsabilidade social em todas as áreas de competência da União Européia, em especial ao nível dos financiamentos regionais e sociais, e criar, à escala comunitária, uma plataforma de discussão multilateral sobre RSE. O Parlamento Europeu apela ainda à publicação, por parte das empresas, de resultados tripartidos, dando conta dos respectivos desempenhos ambientais e sociais, incluindo a dimensão dos direitos humanos.

A Comunicação se destina às instituições européias, aos Estados-Membros, aos parceiros sociais, bem como às associações empresariais e de consumidores, empresas individuais e outros agentes interessados, na medida em que a estratégia européia de promoção da RSE só poderá progredir e ser implementada através da sua ação conjunta. A Comissão convida as empresas e seus agentes associados, bem como os parceiros sociais dos países candidatos, a aderir a esta iniciativa.

\subsection{0 - A Global Reporting Initiative}

A Iniciativa de Relatório Global (GRI) é um acordo internacional, criado com uma visão de longo prazo, multi-stakeholder, cuja missão é elaborar e difundir as Diretrizes para elaboração de Relatórios de Sustentabilidade aplicáveis globalmente e voluntariamente pelas organizações que desejam dar informação sobre os aspectos econômicos, ambientais e sociais das suas atividades, produtos e serviços.

A GRI surgiu de uma parceria entre a CERES (Coalition for Environmentally Responsible Economies) e o Programa Ambiental das Nações Unidas em 1997.

As Diretrizes para a elaboração dos Relatórios de Sustentabilidade abordam os três elementos interrelacionados da sustentabilidade tal como se aplicam a uma organização.

Econômicos - incluem por exemplo, os gastos e benefícios, produtividade do trabalho, criação de emprego, despesas em serviços externos, despesas em investigação e desenvolvimento e investimentos em educação e outras formas de capital humano. Engloba fatores como: a geração de empregos diretos ou indiretos; o retorno dos investimentos para o negócio e para a comunidade; os investimentos na melhoria da cadeia produtiva; os impactos econômicos gerados pela abertura de novos negócios ou pelo fechamento de unidades da empresa. Por outro lado, pode-se observar que a sociedade está se tornando cada vez mais solidária, desencantada do poder público 
Revista Eletrônica de Ciência Administrativa (RECADM) - ISSN 1677-7387 Faculdade Cenecista de Campo Largo - Coordenação do Curso de Administração v. 4, n. 1, maio/2005 - http://revistas.facecla.com.br/index.php/recadm/

para solucionar problemas sociais que se agravam a cada dia, como a violência urbana, a miséria, o desemprego, as deficiências na prestação de serviços de saúde e educação. Mais e mais pessoas estão apoiando causas de interesse social protagonizadas pela sociedade civil. A razão de ser do seu negócio é ser produtivo e rentável, mas também, ao mesmo tempo, atendendo às necessidades humanas e contribuindo para o bem de todos.

Ambientais - incluem, por exemplo, impactos dos processos, produtos e serviços no ar, água, solo, biodiversidade e saúde humana. Ao interagir com o meio ambiente, a empresa causa impactos que podem estar relacionados ao ar, à água, ao solo ou à biodiversidade de animais e vegetais. Hoje, todos sabem que a existência de um negócio também se justifica pelo seu compromisso com a preservação do meio ambiente. Uma empresa ambientalmente responsável evita provocar danos ao meio ambiente e auxilia na sua preservação. Além do mais, divulga para outras empresas práticas e conhecimentos adquiridos sobre o tema.

Sociais - incluem, por exemplo, a saúde e segurança ocupacionais, estabilidade do empregado, direito trabalhista, direitos humanos, salários e condições de trabalho nas operações externas. Buscam a promoção do bem-estar da força de trabalho; a defesa dos direitos dos trabalhadores e dos direitos humanos; a melhoria das condições de trabalho; o estreitamento das relações entre empresários e colaboradores; a implementação da diversidade, isto é, a contratação de pessoas discriminadas por qualquer tipo de preconceito: idade, deficiência física e outros; a promoção de programas para melhorar a qualificação desses grupos de pessoas. A figura 4 detalha os elementos interrelacionados da sustentabilidade.

Figura 4 - Elementos interrelacionados da sustentabilidade

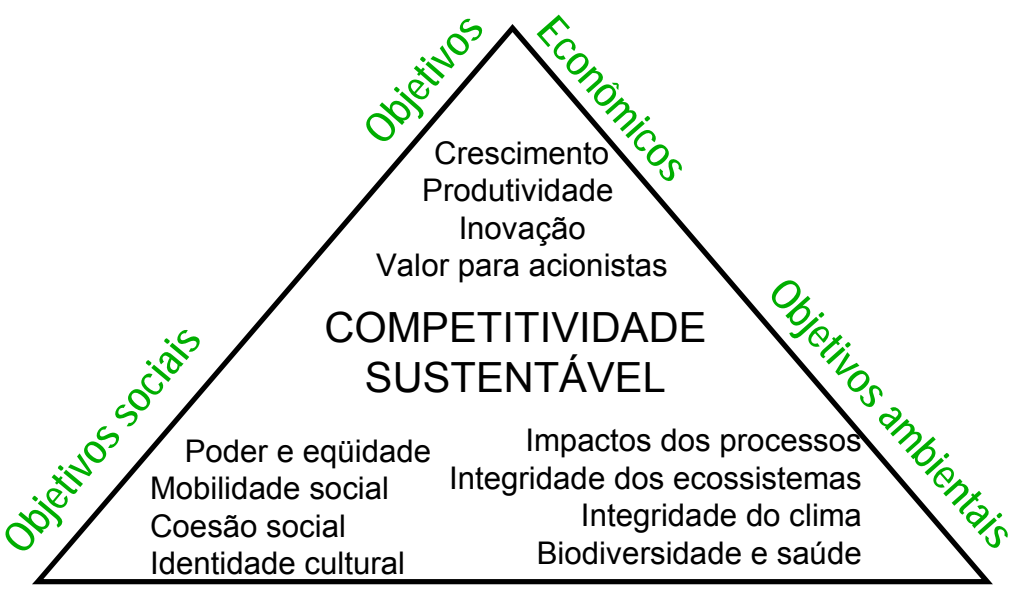

Fonte: Grassi (2004) 
Revista Eletrônica de Ciência Administrativa (RECADM) - ISSN 1677-7387 Faculdade Cenecista de Campo Largo - Coordenação do Curso de Administração v. 4 , n. 1, maio/2005 - http://revistas.facecla.com.br/index.php/recadm/

Estas Diretrizes fornecem um enquadramento para apresentar os Relatórios de Sustentabilidade, promovendo as possibilidades de comparação entre diferentes organizações, ao mesmo tempo em que reconhecem a utilidade de compilar e apresentar a informação. As Diretrizes compreendem quatro partes:

$\rightarrow$ Introdução e orientação geral - informação básica para compreender a necessidade e a natureza da GRI, assim como linhas gerais sobre a concepção e aplicabilidade das Diretrizes.

$\rightarrow$ Princípios e métodos para a elaboração de Relatórios de Sustentabilidade aspectos fundamentais, conceitos e práticas que promovem o rigor, a comparabilidade, e a fiabilidade na elaboração dos relatórios.

$\rightarrow$ Conteúdo do Relatório da Sustentabilidade - enquadramento para estruturar um relatório GRI, conteúdo específico e conselhos para completar as várias partes do relatório.

$\rightarrow$ Anexos - orientação adicional e recursos para utilizar as Diretrizes.

A GRI visa ajudar as organizações a elaborar os relatórios de modo a que:

$\rightarrow$ apresentem uma visão clara do impacto ecológico e humano da empresa, para apoiar a tomada de decisões fundamentadas quanto a investimentos, compras e possíveis alianças;

$\rightarrow$ proporcionem, às partes interessadas (stakeholders), informação credível que seja relevante para as suas necessidades e interesses e que convide a um maior diálogo e informação com as partes interessadas.;

$\rightarrow$ proporcionem uma ferramenta de gestão para apoiar a organização na avaliação e melhoria contínua do seu desempenho e progresso;

$\rightarrow$ respeitem critérios externos já estabelecidos e comumente aceitos para elaboração de relatórios e os apliquem consistentemente nos sucessivos períodos informativos para garantir transparência e credibilidade;

$\rightarrow$ apresentem-se num formato que seja facilmente compreensível e que facilite a comparação com Relatórios de Sustentabilidade de outras organizações;

$\rightarrow$ complementem, e não substituam, outras formas de comunicação, incluindo financeira;

$\rightarrow$ ilustrem a relação entre os três elementos da sustentabilidade - econômico, ambiental e social.

A GRI é uma ferramenta valiosa no processo de tomada de decisões em três níveis:

$\rightarrow$ Em nível operacional, as Diretrizes proporcionam uma estrutura lógica para aplicar o conceito de sustentabilidade ao funcionamento, serviços e produtos das organizações. Também dão orientação quanto à criação de sistemas de recolha de dados e informação 
Revista Eletrônica de Ciência Administrativa (RECADM) - ISSN 1677-7387

Faculdade Cenecista de Campo Largo - Coordenação do Curso de Administração v. 4, n. 1, maio/2005 - http://revistas.facecla.com.br/index.php/recadm/

para estimular e controlar os progressos em relação a objetivos econômicos, ambientais e sociais.

$\rightarrow$ Em nível do Conselho de Administração, as Diretrizes são um veículo interno para avaliar a consistência entre as políticas e o desempenho atual em termos econômico, ambiental e social da organização. Conseguir uma maior uniformidade na elaboração dos relatórios mediante a utilização das Diretrizes ajudará as organizações a se comparar com outras e a serem reconhecidas para melhoria contínua do seu desempenho.

$\rightarrow$ De um ponto de vista de comunicação empresarial, as Diretrizes constituem um marco para promover efetivamente um diálogo e um intercâmbio de informação com as partes interessadas internas e externas, relacionados com os benefícios e desafios das empresas para atingir os seus objetivos.

À medida que a maioria das empresas decida adotar as Diretrizes, as oportunidades de comparar o desempenho dentro e através de setores e países reforçarão a capacidade das partes interessantes para impulsionar contínuos progressos nas práticas empresarias compatíveis com a sustentabilidade.

A GRI inclui hipóteses e características qualitativas da informação sobre sustentabilidade análogas às das contábeis. Deste modo, os princípios de informação da GRI se estruturam em cinco partes: hipóteses subjacentes, características qualitativas, classificação de elementos, indicadores e políticas de informação. Os princípios subjacentes e as características qualitativas da informação sobre a sustentabilidade da organização aparecem no quadro 5.

Quadro 5 - Princípios subjacentes e características qualitativas da informação sobre sustentabilidade.

\section{Princípios ou Hipóteses Subjacentes}

\begin{tabular}{|l|l|}
\hline Entidade & $\begin{array}{l}\text { Deve ampliar seus limites contábeis para compilar o efeito completo } \\
\text { de seus produtos ou serviços. }\end{array}$ \\
\hline Alcance & $\begin{array}{l}\text { Compilar os aspectos econômicos, sociais e ambientais, assim } \\
\text { como integrá-los. }\end{array}$ \\
\hline $\begin{array}{l}\text { Período } \\
\text { informativo }\end{array}$ & $\begin{array}{l}\text { A informação deve ser proporcionada no período em que se } \\
\text { produza o efeito. }\end{array}$ \\
\hline $\begin{array}{l}\text { Empresa em } \\
\text { funcionamento }\end{array}$ & $\begin{array}{l}\text { A continuidade da empresa é função de aspectos econômicos, } \\
\text { sociais e ambientais. }\end{array}$ \\
\hline Conservadorismo & $\begin{array}{l}\text { A informação não deve proporcionar uma imagem otimista acerca } \\
\text { da sustentabilidade da empresa. }\end{array}$ \\
\hline Materialidade & $\begin{array}{l}\text { Proporcionar informação sobre ações relevantes para a empresa e } \\
\text { seus stakeholders. }\end{array}$ \\
\hline Características Qualitativas \\
\hline Relevância & Resposta aos interesses e necessidades dos partícipes. \\
\hline Fiabilidade & $\begin{array}{l}\text { Descrição válida das ações: objetiva e lógica } \\
\text { Neutralidade: aspectos positivos e negativos } \\
\text { Integridade: efeitos diretos e indiretos } \\
\text { Prudência: sobre aspectos positivos e negativos }\end{array}$ \\
\hline
\end{tabular}


Revista Eletrônica de Ciência Administrativa (RECADM) - ISSN 1677-7387 Faculdade Cenecista de Campo Largo - Coordenação do Curso de Administração v. 4, n. 1, maio/2005 - http://revistas.facecla.com.br/index.php/recadm/

\begin{tabular}{|l|l|}
\hline Clareza & $\begin{array}{l}\text { Dirigida a stakeholders com conhecimentos básicos nos três } \\
\text { aspectos. }\end{array}$ \\
\hline Comparabilidade & $\begin{array}{l}\text { A informação deve ser comparável ao longo de vários períodos e } \\
\text { entre diferentes organizações. }\end{array}$ \\
\hline Oportunidade & $\begin{array}{l}\text { Arbitrar meios para comunicar as ações em função de seu impacto } \\
\text { (acidentes ecológicos). }\end{array}$ \\
\hline Verificabilidade & A informação deve ser suscetível de verificação. \\
\hline
\end{tabular}

Fonte: González \& Abadía (2002)

Quanto ao princípio de alcance, o informe deve expressar de forma clara quais temas têm cobertura entre os que propõe a GRI: ambiental, econômico e social.

$O$ princípio da importância relativa requer interação com o consenso dos stakeholders ou partícipes da empresa. A relevância da informação também se determina tendo em conta os interesses e as necessidades dos diferentes partícipes.

A fiabilidade da informação requer que esta seja exata, completa e neutra. A informação é completa na medida que o informe não omite nenhum aspecto dentre os propostos para cada dimensão da sustentabilidade, especialmente aqueles que mostram uma imagem menos favorecedora para a empresa.

O conteúdo dos informes de sustentabilidade se estrutura de acordo com uma hierarquia que começa com a definição de categorias, ou áreas extensas, sobre questões econômicas, sociais ou ambientais de interesses para os partícipes. No aspecto social, se distingue neste documento as categorias "condições de trabalho", "direitos humanos", "fornecedores" e "produtos e serviços". Os aspectos estão relacionados com as categorias, podendo uma categoria incluir vários aspectos. Dentro dos direitos humanos, a GRI distingue entre os seguintes aspectos: geral, direitos dos povos indígenas e segurança. Estes indicadores permitirão proporcionar informação, normalmente quantitativa, sobre os diferentes aspectos, podendo desenvolver, nestes, diferentes indicadores.

As Diretrizes GRI contêm recomendações para a avaliação da sustentabilidade, contemplando indicadores de desempenho agrupados em três secções, abrangendo as dimensões econômica, ambiental e social. A GRI estabeleceu uma hierarquia de elementos de informação para cada uma das dimensões da sustentabilidade, observando três níveis:

$\sqrt{ }$ Categorias - áreas ou agrupamentos das questões econômicas, ambientais ou sociais que afetam as partes interessadas.

$\checkmark$ Aspectos - elementos relacionados com uma categoria específica. Uma dada categoria pode conter vários aspectos.

$\checkmark$ Indicadores - valores específicos de um aspecto concreto que possam ser utilizados para acompanhar e demonstrar o desempenho. A GRI admite que os indicadores possam ser quantitativos ou qualitativos. 
Revista Eletrônica de Ciência Administrativa (RECADM) - ISSN 1677-7387

Faculdade Cenecista de Campo Largo - Coordenação do Curso de Administração

v. 4, n. 1, maio/2005 - http://revistas.facecla.com.br/index.php/recadm/

$\mathrm{Na}$ figura 5 estão sintetizados as categorias e os aspectos contemplados pela GRI. As Diretrizes contêm ainda uma descrição pormenorizada dos indicadores que devem ser utilizados para caracterizar os diferentes aspectos.

Figura 5 - Categorias e aspectos contemplados nas Diretrizes GRI (GRI, 2002)

\begin{tabular}{|c|c|c|}
\hline & CATEGORIA & ASPECTO \\
\hline \multirow{2}{*}{$\begin{array}{l}8 \\
8 \\
\frac{3}{8} \\
8 \\
8 \\
0\end{array}$} & $\begin{array}{l}\text { Impactes Económicos } \\
\text { Directos }\end{array}$ & $\begin{array}{l}\text { Clientes } \\
\text { Fornecedores } \\
\text { Empregados } \\
\text { Fornecedores de capital } \\
\text { Sector público }\end{array}$ \\
\hline & $\begin{array}{l}\text { Impactes Económicos } \\
\text { Indirectos }\end{array}$ & Externalidades \\
\hline$\frac{\frac{y}{2}}{\frac{5}{2}}$ & Ambientais & $\begin{array}{l}\text { Materiais } \\
\text { Energia } \\
\text { Áqua } \\
\text { Biodiversidade } \\
\text { Emissőes, efluentes e residuos } \\
\text { Fornecedores } \\
\text { Produtos e serviços } \\
\text { Cumprimento } \\
\text { Transporte } \\
\text { Global }\end{array}$ \\
\hline \multirow{4}{*}{$\frac{2}{8}$} & $\begin{array}{l}\text { Práticas Laborais e Condiçóes } \\
\text { de Trabalho }\end{array}$ & $\begin{array}{l}\text { Empreqo } \\
\text { Relaç̋es trabalhadores/qestão } \\
\text { Saúde e sequrança } \\
\text { Treino e educação } \\
\text { Diversidade e oportunidades }\end{array}$ \\
\hline & Direitos Humanos & $\begin{array}{l}\text { Estratéqia e qestão } \\
\text { Năo-discriminaç̃o } \\
\text { Liberdade de associaçăo e negociação colectiva } \\
\text { Trabalho infantil } \\
\text { Trabalho forçado e compulsório } \\
\text { Práticas disciplinares } \\
\text { Práticas de sequrança } \\
\text { Direitos dos nativos }\end{array}$ \\
\hline & Sociedade & $\begin{array}{l}\text { Comunidade } \\
\text { Suborno e corrupç̃o } \\
\text { Contributos políticos } \\
\text { Competição e preços }\end{array}$ \\
\hline & $\begin{array}{l}\text { Responsabilidade pelos } \\
\text { Produtos }\end{array}$ & $\begin{array}{l}\text { Saúde e segurança dos clientes } \\
\text { Produtos e serviços } \\
\text { Publicidade } \\
\text { Respeito pela privacidade }\end{array}$ \\
\hline
\end{tabular}

Fonte: http://www.globalreporting.org

Os indicadores para a elaboração dos relatórios abordam os três elementos interrelacionados da sustentabilidade, tal como se aplicam a uma organização, como segue no quadro 6 .

Quadro 6 - Elementos e indicadores

\begin{tabular}{|l|l|}
\hline Econômico & $\begin{array}{l}\text { Inclui, por exemplo, os gastos e benefícios, produtividade no trabalho, } \\
\text { criação de emprego, despesas em serviços externos, despesas em } \\
\text { investigação e desenvolvimento, investimentos em educação e outras } \\
\text { formas de capital humano. O aspecto econômico inclui, embora não se } \\
\text { limite só a ele, a informação financeira e respectivas declarações. }\end{array}$ \\
\hline
\end{tabular}


Revista Eletrônica de Ciência Administrativa (RECADM) - ISSN 1677-7387 Faculdade Cenecista de Campo Largo - Coordenação do Curso de Administração v. 4, n. 1, maio/2005 - http://revistas.facecla.com.br/index.php/recadm/

\begin{tabular}{|l|l|}
\hline Ambiental & $\begin{array}{l}\text { Inclui, por exemplo, impacto dos processos, produtos, serviços no ar, } \\
\text { água, solo, biodiversidade e saúde humana. }\end{array}$ \\
\hline Social & $\begin{array}{l}\text { Inclui, por exemplo, o tratamento que se dá aos grupos minoritários e às } \\
\text { mulheres, o trabalho feito em favor dos menores, a saúde e segurança } \\
\text { ocupacionais, estabilidade do empregado, direito trabalhista, direitos } \\
\text { humanos, salários e condições de trabalho nas relações externas. }\end{array}$ \\
\hline
\end{tabular}
Fonte:http://www.globalreporting.org

De certa forma, a GRI completou o Global Compacto (Pacto Global) porque tenta transformar seus princípios em algo mensurável e verificável. Seus relatórios permitem que as partes interessadas externas, especialmente investidores e sociedade civil, possam avaliar e acompanhar como as empresas signatárias estão implementando os nove princípios do Global Compact.

Em 2002, a GRI lançou a segunda versão de suas diretrizes, as Sustainability Reporting Guidelines (Diretrizes para Relatórios de Sustentabilidade). Elas buscam garantir que os compromissos assumidos com o meio ambiente, o trabalho e os direitos humanos se transformem em ações concretas e em melhorias crescentes. Para tal, a GRI supõe que os relatórios apresentados pelas empresas sigam alguns princípios. Esses princípios são agrupados em quatro categorias, conforme a figura 6.

Figura 6 - Relatório dos Princípios

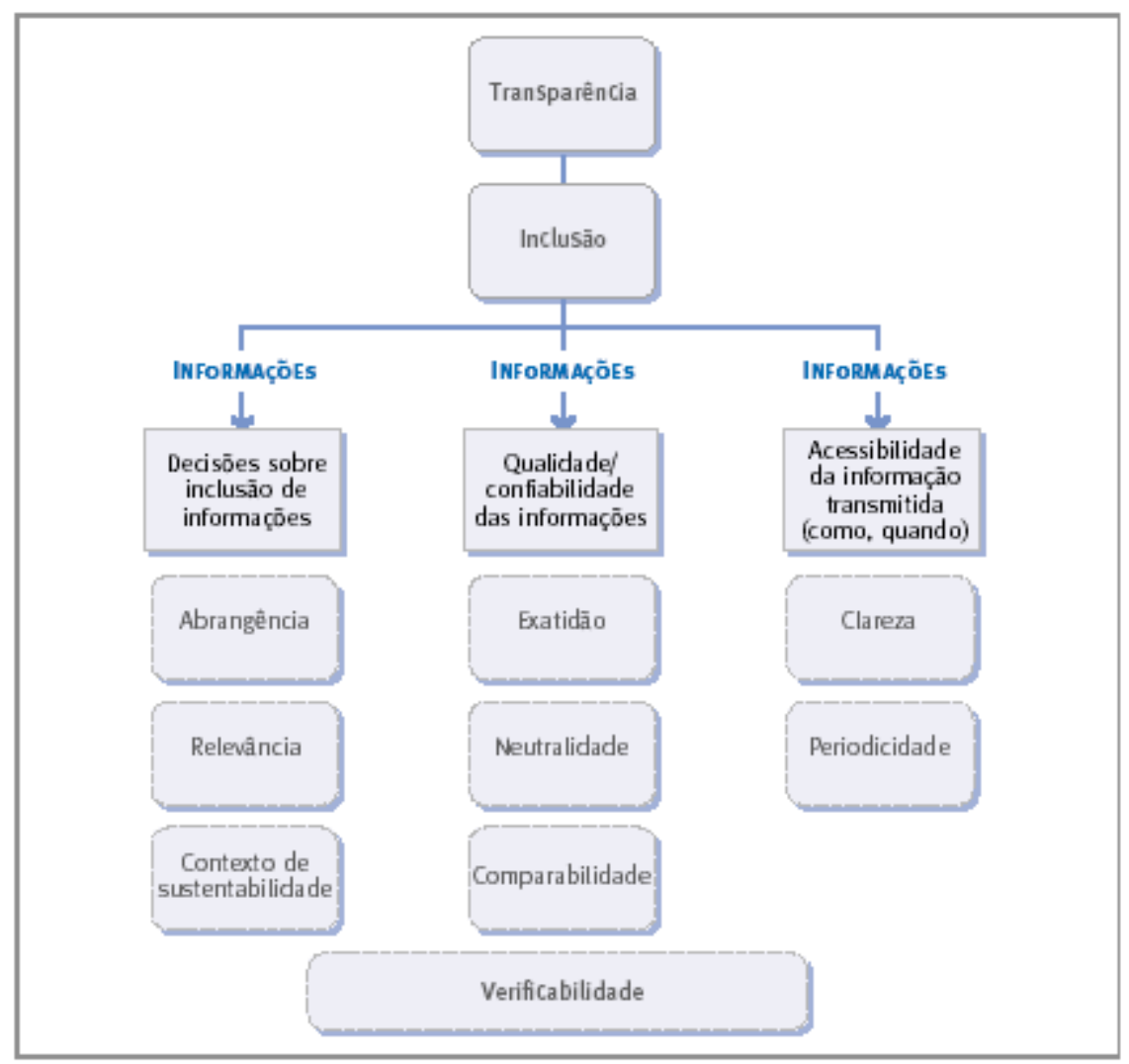

Fonte: http://www.globalreporting.org/ 
Revista Eletrônica de Ciência Administrativa (RECADM) - ISSN 1677-7387

Faculdade Cenecista de Campo Largo - Coordenação do Curso de Administração v. 4, n. 1, maio/2005 - http://revistas.facecla.com.br/index.php/recadm/

$\rightarrow$ os que constituem a estrutura do relatório (transparência, inclusão e verificabilidade);

$\rightarrow$ os que auxiliam as decisões sobre a inclusão nos relatórios (abrangência, relevância, contexto de sustentabilidade);

$\rightarrow$ os que se relacionam com garantias de qualidade e de confiabilidade (exatidão, neutralidade, comparabilidade);

$\rightarrow$ os que auxiliam nas decisões sobre acesso ao relatório (clareza e periodicidade).

Os 11 princípios são os que seguem:

$\rightarrow$ Transparência - A completa publicação de processos, procedimentos e suposições na preparação do relatório é essencial para sua credibilidade.

$\rightarrow$ Inclusão - A organização deve sistematicamente engajar suas partes interessadas para ajudar a focar e melhorar continuamente a qualidade de seus relatórios.

$\rightarrow$ Verificabilidade - Dados e informação relatados devem ser registrados, compilados, analisados e revelados de modo a permitir que auditores internos ou provedores de garantia externos possam atestar a sua veracidade.

$\rightarrow$ Abrangência - Todas as informações materiais aos usuários para avaliar o desempenho econômico, ambiental e social da organização devem aparecer no relatório de maneira consistente com os limites, escopo e período de tempo declarados.

$\rightarrow$ Relevância - A relevância é o grau de importância dado a um particular aspecto, indicador ou pedaço de informação e representa o ponto no qual a informação se torna significante o suficiente para ser relatada.

$\rightarrow$ Contexto de Sustentabilidade - A organização deve procurar colocar seu desempenho no contexto mais amplo do ecológico, social, ou outros limites ou restrições, onde tal contexto adicione significado importante à informação relatada.

$\rightarrow$ Exatidão - O princípio da exatidão se refere a alcançar o grau de exatidão e baixa margem de erro na informação relatada necessária para que os usuários tomem decisões com um alto grau de segurança.

$\rightarrow$ Neutralidade - Os relatórios devem evitar indução na seleção e apresentação da informação e devem se esforçar para dar uma conta balanceada do desempenho da organização.

$\rightarrow$ Comparabilidade - A organização deve manter a consistência no limite e escopo de seus relatórios, publicando qualquer mudança, e reafirmando previamente a informação relatada.

$\rightarrow$ Clareza - A organização deve permanecer consciente das diversas necessidades e backgrounds de todos os grupos de partes interessadas e deve deixar a informação disponível de maneira pró-ativa ao máximo número de usuários, enquanto ainda mantenha um adequado nível de detalhe. 
Revista Eletrônica de Ciência Administrativa (RECADM) - ISSN 1677-7387 Faculdade Cenecista de Campo Largo - Coordenação do Curso de Administração v. 4, n. 1, maio/2005 - http://revistas.facecla.com.br/index.php/recadm/

$\rightarrow$ Periodicidade - Os relatórios devem providenciar informação em um calendário regular que preencha as necessidades dos usuários e comporte a natureza da própria informação.

Os princípios da transparência e de inclusão representam o ponto inicial para o processo de relato. Todas as decisões sobre o relato (ex: como, quando, o que) levam estes dois princípios e práticas associadas em consideração.

Os princípios do contexto de sustentabilidade, de abrangência e de relevância têm papel chave na determinação do que relatar. A informação contida dentro do relatório deve passar no teste da completude em termos dos limites do relato, escopo e período de tempo. Por último, a informação relatada deve ser relevante às necessidades das partes interessadas.

A qualidade e confiabilidade do conteúdo do relatório são guiadas pelos princípios da neutralidade, comparabilidade e exatidão. Relatórios devem ser comparáveis através do tempo e entre organizações. As informações devem ser suficientemente exatas e confiáveis para permitir seu uso para propósitos de tomada de decisão. Igualmente importante, o relatório deve apresentar seu conteúdo de forma balanceada e imparcial.

Os princípios da clareza e periodicidade governam o acesso e a disponibilidade dos relatórios, isto é, as partes interessadas devem receber facilmente informação entendível em um período de tempo que as permite utilizá-la efetivamente.

Por último, o princípio da verificabilidade se relaciona com vários outros princípios como a comparabilidade, relevância, neutralidade e abrangência. Especificamente, este princípio se refere à capacidade de demonstrar que os processos por trás da preparação do relatório e a própria informação do relatório seguem padrões de qualidade, veracidade e outras expectativas similares.

O GRI é um marco para a comunicação (externa) de informação para as empresas no que diz respeito a:

$\sqrt{ }$ suas atuações para melhorar a sustentabilidade;

$\checkmark$ os resultados destas atuações.

O GRI não oferece nenhum modelo de Balanço Social. O que propõe se baseia no conceito de sustentabilidade. Busca transformar a elaboração destes relatórios sobre sustentabilidade uma rotina e conferir-lhes credibilidade como as demonstrações financeiras em termos de comparabilidade, rigor e verificabilidade.

\subsection{1 - NORMA SA 8000 - ou Social Accountability (Responsabilidade Social)}

A SA 8000 é uma norma internacional que visa aprimorar o bem-estar e as boas condições de trabalho, bem como o desenvolvimento de um sistema de verificação que garanta a contínua conformidade com os padrões estabelecidos pela norma.É o 
Revista Eletrônica de Ciência Administrativa (RECADM) - ISSN 1677-7387

Faculdade Cenecista de Campo Largo - Coordenação do Curso de Administração v. 4, n. 1, maio/2005 - http://revistas.facecla.com.br/index.php/recadm/

primeiro padrão de certificação social que busca garantir os direitos básicos dos trabalhadores. Quem credencia as organizações qualificadas para verificar a conformidade é a Social Accountability International - SAI (Responsabilidade Social Internacional).

Criada em 1997, baseia-se no sistema de auditoria da ISO 9000 e está voltada para o sistema de gestão empresarial. Sua inspiração são os princípios das convenções internacionais sobre direitos humanos. Sua finalidade é ser um sistema de implementação, manutenção e verificação de melhores condições de trabalho, por meio de uma norma universal para todos os ramos de negócios e setores, que pode ser auditável, passível de certificação e de verificação por terceiros.

A SA 8000 constitui um instrumento de informação extremamente importante para o consumidor globalizado, pois, atualmente, os fatores determinantes da sua escolha vão além de preço e qualidade. As pessoas necessitam saber como o produto ou serviço que estão adquirindo foi produzido, repudiando imediatamente aqueles que agregam procedimentos como, por exemplo, o trabalho infantil. Além de proteger a reputação das organizações e a integridade das marcas, a SA 8000 possibilita às companhias de todo o mundo externarem seus valores éticos e seu grau de envolvimento social, aspectos fundamentais frente a um consumidor-cidadão cada vez mais participante e vigilante. $O$ quadro 7 mostra alguns dos principais pontos apresentados pela norma SA 8000.

Quadro 7 - Principais pontos da Norma SA 8000

\begin{tabular}{|l|l|}
\hline Trabalho infantil & $\begin{array}{l}\text { É proibida a contratação de crianças de 15 anos ou menos. Se exist } \\
\text { funcionários nessa faixa etária, eles não poderão ser demitidos. Nesse caso, } \\
\text { responsabilidade da empresa assegurar sua educação. }\end{array}$ \\
\hline $\begin{array}{l}\text { Liberdade de } \\
\text { associação e direito } \\
\text { à negociação } \\
\text { coletiva }\end{array}$ & $\begin{array}{l}\text { Protege o direito dos trabalhadores de formar sindicatos e se afiliar a grı } \\
\text { organizados. }\end{array}$ \\
\hline Discriminação & $\begin{array}{l}\text { Proíbe a discriminação baseada na cor, nacionalidade, religião, deficiência fí } \\
\text { sexo, orientação sexual, afiliação a sindicato ou partido político. }\end{array}$ \\
\hline Horário de trabalho & $\begin{array}{l}\text { A jornada normal deverá ser de 44 horas semanais. As horas extras deven } \\
\text { voluntárias e ter caráter temporário, não devendo exceder 12 horas semanais. }\end{array}$ \\
\hline Práticas disciplinares & $\begin{array}{l}\text { Proíbe punição física, coerção e abuso verbal no uso da disciplina. A emp } \\
\text { também deve impedir comportamentos, como gestos, linguagem e contato fí } \\
\text { que sejam sexualmente coercitivos, ameaçadores, abusivos ou exploratórios. }\end{array}$ \\
\hline Comunicação & $\begin{array}{l}\text { A política de responsabilidade social deve ser documentada, implementac } \\
\text { comunicada a todos os funcionários. }\end{array}$ \\
\hline
\end{tabular}

Fonte: Revista Exame - Guia de boa cidadania corporativa (2001)

A SA 8000 é cada vez mais reconhecida no mundo como um sistema efetivo de implementação, manutenção e verificação de condições dignas de trabalho. Atualmente são mais de 160 empresas certificadas com SA 8000 em diversos países, incluindo, entre outros: Estados Unidos, Inglaterra, Espanha, Itália e Brasil. 
Revista Eletrônica de Ciência Administrativa (RECADM) - ISSN 1677-7387 Faculdade Cenecista de Campo Largo - Coordenação do Curso de Administração v. 4 , n. 1, maio/2005 - http://revistas.facecla.com.br/index.php/recadm/

Várias empresas multinacionais nos Estados Unidos e na Europa estão implementando a norma SA 8000 e exigindo que seus fornecedores operem dentro destes padrões.

A norma SA 8000 apresenta-se como um sistema de auditoria similar ao ISO 9000, que atualmente é apresentado por mais de 300.000 empresas em todo o mundo. Seus requisitos são baseados nas normas internacionais de direitos humanos e nas convenções da OIT.

A SA 8000 aborda nove questões específicas ou requisitos de responsabilidade social:

$\rightarrow$ Os cinco direitos fundamentais da OIT (trabalho infantil, trabalho forçado, saúde e segurança, liberdade de associação e direito à negociação coletiva e discriminação).

$\rightarrow$ Práticas disciplinares (a empresa não pode apoiar ou utilizar qualquer prática de punição corporal, coação física ou mental e ofensa verbal contra seus empregados. Estão incluídas neste item práticas como descontos arbitrários na folha de pagamento e ameaças de demissão).

$\rightarrow$ Horários de trabalho (não excedendo às 48 horas semanais, respeitando a folgas semanal e as regras da hora extra).

$\rightarrow$ Remuneração.

$\rightarrow$ Sistema de gestão.

Desenvolvida por um conselho internacional que reúne empresários, ONGs e organizações sindicais, a SA 8000 quer encorajar a participação de todos os setores da sociedade na busca de boas e dignas condições de trabalho.

\subsection{2 - NORMA AA 1000 ou AccountAbility}

A AA 1000 (AccountAbility 1000) é um padrão de processo para a gestão da contabilidade, auditoria e relato da responsabilidade corporativa. Seu principal diferencial está na inclusão das partes interessadas em todos os seus passos, dando credibilidade à responsabilidade corporativa da organização que o adota.

Desenvolvida e lançada em novembro de 1999 pelo Institute of Social and Ethical Accountability - ISEA, de Londres (Reino Unido), a norma AA 1000 tem o desafio de ser o primeiro padrão internacional de gestão de responsabilidade corporativa. A versão preliminar da Estrutura AA 1000 foi testada em projetos-piloto em várias organizações que realizaram uma auditoria social e ética em seu planejamento e gestão estratégica.

Entre as organizações que estão utilizando e apoiando este padrão estão multinacionais como a Shell International (Reino Unido), Novo Nordisk (Dinamarca) e British American Tobacco (BAT). The Body Shop Plc e Co-operative Bank (ambos do 
Revista Eletrônica de Ciência Administrativa (RECADM) - ISSN 1677-7387 Faculdade Cenecista de Campo Largo - Coordenação do Curso de Administração v. 4, n. 1, maio/2005 - http://revistas.facecla.com.br/index.php/recadm/

Reino Unido) foram os primeiros a publicar relatórios sociais integralmente baseados na aplicação do padrão AA1000.

Foi criada para assistir organizações na definição de objetivos e metas, na medição do progresso em relação a estas metas, na auditoria e relato da performance e no estabelecimento de mecanismos de feedback Compreende princípios e normas de processo. Os estágios das normas de processo são: planejamento; responsabilidade; auditoria e relato; integração de sistemas; comprometimento dos stakeholders.

As normas de processo da AA 1000 associam a definição e a integração de sistemas dos valores da organização com o desenvolvimento das metas de desempenho e com a avaliação e comunicação do desempenho organizacional.

Por este processo, focalizado no comprometimento da organização para os stakeholders, a AA 1000 vincula as questões sociais e éticas à gestão estratégica e às operações da organização.

Em 2002, o ISEA - que hoje é o órgão que formalmente regula o padrão e monitora o treinamento dos consultores da AA 1000 -realizou uma fase de consulta a stakeholders, avaliou as primeiras experiências em detalhe e revisou o padrão, complementando-o com cinco módulos individuais que compõem a Série AA 1000 (AA 1000S). É um padrão básico de responsabilidade para melhorar a qualidade do processo de contabilidade, auditoria e relato. Não é um padrão certificável e sim um instrumento verificável de mudança organizacional, derivado da melhoria contínua e de aprendizagem e inovação para "servir de modelo do processo a seguir na elaboração; proporcionar mais qualidade a outros padrões específicos e complemento a outras iniciativas".

A organização (empresarial, não-lucrativa ou governamental) que adota a AA 1000 deve seguir um processo contínuo de ciclos de atividades que têm como principais passos a definição ou redefinição de valores, desenvolvimento de metas de performance ética e social e avaliação e comunicação do desempenho em relação às metas desenvolvidas.

No processo AA 1000, o envolvimento dos stakeholders ou partes interessadas nas atividades da organização é crucial. Isto quer dizer que a organização deve utilizar sua liderança para possibilitar e ampliar seu diálogo com funcionários, clientes, fornecedores, comunidades, governo, representantes do meio ambiente, acionistas, entre outros.

É, portanto, justamente esse processo de sistematização do envolvimento de stakeholders que legitima a empresa como sendo socialmente responsável, tornando as informações, levadas a público pela organização, mais confiáveis.

Fazem parte da norma oito princípios de qualidade especificados a seguir, agrupados por área de referência: 
Revista Eletrônica de Ciência Administrativa (RECADM) - ISSN 1677-7387

Faculdade Cenecista de Campo Largo - Coordenação do Curso de Administração v. 4, n. 1, maio/2005 - http://revistas.facecla.com.br/index.php/recadm/

\begin{tabular}{|lr|l|l|}
\hline $\begin{array}{l}\text { Escopo e natureza do } \\
\text { processo }\end{array}$ & Significado da informação & $\begin{array}{l}\text { Gestão de processo } \\
\text { contínuo }\end{array}$ \\
\hline $\begin{array}{l}\rightarrow \text { Completude } \\
\rightarrow \text { Materialidade } \\
\begin{array}{l}\text { Regularidade } \\
\text { oportunidade }\end{array}\end{array}$ & $\begin{array}{l}\rightarrow \text { Garantia de qualidade } \\
\text { dos dados } \\
\rightarrow \text { Acessibilidade } \\
\rightarrow \text { Qualidade da informação }\end{array}$ & $\begin{array}{l}\rightarrow \text { Integração de sistemas } \\
\rightarrow \text { Melhoria contínua }\end{array}$ \\
\hline
\end{tabular}

O próprio processo segue um ciclo definido de atividades agrupadas nos cinco elementos do processo AA 1000:

1. Planejamento (Planning)

2. Contabilidade social (Accounting)

3. Auditoria e relatório social (Auditing and Reporting)

4. Integração dos sistemas (Embedding)

5. Diálogo com stakeholders (Stakeholder dialogue)

Os elementos 4 e 5 são os fundamentos de todo o processo. A inclusão dos stakeholders é uma característica que distingue o processo AA 1000 de todos os outros sistemas de gestão. O relato é um importante elemento do processo e a AA $1000 \mathrm{~S}$ se baseia integralmente no padrão de relato GRI, para o qual faz referência e contribui como um parceiro essencial.

\subsection{1 - Benefícios}

A melhoria do desempenho social, traduzido em maior confiança, comprometimento, lealdade e produtividade, ocorre quando o princípio da responsabilidade social corporativa está sendo posta em prática, ou seja, quando a empresa inclui e considera, em suas decisões estratégicas, a visão e opinião de todos os grupos que estão envolvidos ou são impactados pelas atividades da empresa.

Como foi dito anteriormente, o ISEA, num esforço de aperfeiçoamento contínuo, estabeleceu uma fase de consulta a partes interessadas para revisão da norma e apresentação de uma série de módulos para uma versão mais aprofundada, a AA 1000S. O primeiro destes novos elementos, sobre a Garantia da Qualidade e Verificação Externa, foi lançado no final de 2002.

Os módulos a serem lançados em 2003 abordam os seguintes temas: Medição e Comunicação da Qualidade do Engajamento de Partes Interessadas1, Integração de Processos de Accountability2 com Sistemas de Gestão e Medição Existentes, Governança e Gerenciamento de Risco, e Gestão de Accountability para Pequenas Organizações.

O processo AA 1000 pode apoiar a gestão estratégica e as operações de uma organização, dando a ela assistência para:

a) alinhar seus sistemas e atividades com seus valores; 
Revista Eletrônica de Ciência Administrativa (RECADM) - ISSN 1677-7387

Faculdade Cenecista de Campo Largo - Coordenação do Curso de Administração

v. 4, n. 1, maio/2005 - http://revistas.facecla.com.br/index.php/recadm/

b) aprender sobre os impactos de seus sistemas e atividades, incluindo as percepções de partes interessadas sobre esses impactos;

c) servir como parte de uma estrutura para controle interno e para possibilitar à organização identificar, avaliar e melhor gerenciar os riscos que surgem de seus impactos e as relações com suas partes interessadas;

d) atender ao legítimo interesse das partes interessadas em informações a respeito do impacto social e ético das atividades da organização e seus processos de tomada de decisão;

e) construir vantagem competitiva através da projeção de uma postura definida sobre questões sociais e éticas.

\subsection{2 - Princípios}

Fazem parte da norma onze princípios de qualidade que devem ser seguidos pela organização adotante, agrupados a seguir por área de referência:

\section{$\rightarrow$ Escopo e natureza do processo da organização}

$\rightarrow$ Completude- inclusão imparcial nos processos de contabilidade, ao longo do tempo, de todas as áreas apropriadas de atividades relacionadas com o desempenho social e ético da organização.

$\rightarrow$ Materialidade - inclusão de informação significativa que pode afetar um ou mais grupos de partes interessadas e sua avaliação do desempenho social e ético da organização.

$\rightarrow$ Regularidade e Conveniência - necessidade de ação sistemática e na hora certa do processo de contabilidade, auditoria e relato social e ético para apoiar a tomada de decisão da organização e de suas partes interessadas.

\section{$\rightarrow$ Significância da informação}

$\rightarrow$ Garantia da qualidade - através de um processo de auditoria de uma organização por uma terceira parte (auditor) ou partes independentes e competentes.

$\rightarrow$ Acessibilidade - comunicação apropriada e efetiva para as partes interessadas da organização a respeito de seu processo de contabilidade, auditoria e relato social e ético e seu desempenho.

\section{$\rightarrow$ Qualidade da informação}

$\rightarrow$ Comparabilidade - capacidade de comparar informação sobre o desempenho da organização com períodos anteriores, metas de desempenho, e benchmarks externos tirados de outras organizações, regulamentação obrigatória e normas não-obrigatórias.

$\rightarrow$ Confiabilidade - permite à organização e suas partes interessadas dependerem da informação providenciada pela contabilidade, auditoria e relato social e ético para estarem livres de erro ou parcialidade. 
Revista Eletrônica de Ciência Administrativa (RECADM) - ISSN 1677-7387

Faculdade Cenecista de Campo Largo - Coordenação do Curso de Administração v. 4, n. 1, maio/2005 - http://revistas.facecla.com.br/index.php/recadm/

$\rightarrow$ Relevância - utilidade da informação para a organização e suas partes interessadas como um meio de construção de conhecimento e formação de opiniões, e como suporte à tomada de decisão.

$\rightarrow$ Entendimento - compreensão da informação pela organização e suas partes interessadas, incluindo questões de língua, estilo e formato.

\section{$\rightarrow$ Gerenciamento do processo em base contínua}

$\rightarrow$ Integração - ou integração de sistemas, faz com que os processos de contabilidade, auditoria e relato social e ético sejam parte das operações, sistemas e política da organização, e não que sejam tratados como um exercício isolado para produzir um relato social e ético.

$\rightarrow$ Melhoria contínua - os passos, reconhecidos e externamente auditados, que foram dados para melhorar o desempenho em resposta aos resultados do processo de contabilidade, auditoria e relato social e ético e a necessidade por desenvolvimento contínuo do próprio processo de contabilidade, auditoria e relato dentro da organização.

A AA 1000 objetiva apoiar a aprendizagem organizacional e o desempenho geral - social e ético, ambiental e econômico - e, portanto, a contribuição da organização em direção ao caminho do desenvolvimento sustentável. Ela busca alcançar seu objetivo através da melhoria da qualidade da contabilidade, auditoria e relato social e ético.

\section{7 - Responsabilidade social como cultura empresarial}

A visão da responsabilidade social como cultura empresarial está presente nas iniciativas de organismos como a OIT - Organização Internacional do Trabalho e a OCDE - Organização para Cooperação e Desenvolvimento Econômico, que estabeleceram normas e diretrizes para as ações de multinacionais reconhecidas em nível internacional. O objetivo é promover o desenvolvimento econômico a partir de uma perspectiva social e ambientalmente sustentável.

Muitas empresas são atraídas pelas vantagens de adotar práticas socialmente responsáveis. Os principais benefícios para as empresas seriam:

$\rightarrow$ valorização da imagem institucional e da marca;

$\rightarrow$ maior lealdade do consumidor;

$\rightarrow$ maior capacidade de recrutar e manter talentos;

$\rightarrow$ flexibilidade e capacidade de adaptação e

$\rightarrow$ longevidade.

As empresas socialmente responsáveis são aquelas que procuram, além de gerar riquezas, distribuí-las de forma justa entre as diferentes partes interessadas. Para isto é preciso: 
Revista Eletrônica de Ciência Administrativa (RECADM) - ISSN 1677-7387 Faculdade Cenecista de Campo Largo - Coordenação do Curso de Administração v. 4, n. 1, maio/2005 - http://revistas.facecla.com.br/index.php/recadm/

$\rightarrow$ Comprometer-se publicamente a seguir as normas internacionais como definidas pela OIT e a OCDE e envolver as partes interessadas no acompanhamento/monitoramento das suas práticas.

$\rightarrow$ Estabelecer relações saudáveis com as diferentes partes interessadas, levando em conta seus interesses, por meio de mecanismos de consulta e participação.

$\rightarrow$ Procura desenvolver seus negócios de forma a beneficiar a todos, inclusive aos diferentes grupos que compõem a cadeia produtiva.

$\rightarrow$ Na gestão do seu negócio, procurar gerar emprego estável, contribuindo para a justa distribuição das riquezas e reduzindo a exclusão de grandes grupos de cidadãos.

$\rightarrow$ Manter o vínculo do debate sobre responsabilidade social corporativa com as discussões maiores sobre o comércio internacional.

$\rightarrow$ Contribuir para o desenvolvimento da sociedade em que faz parte, fortalecendo suas estruturas democráticas de participação.

$\rightarrow$ Por meio de uma gestão sustentável, inovar na redução de impactos ambientais nãodesejados.

$\rightarrow$ Possuir uma atuação pró-ativa em relação à incorporação das expectativas da sociedade.

Atualmente, fatores como educação, saúde, meio ambiente, segurança, cultura, esporte e lazer são responsáveis pela continuidade de um crescente ciclo de consumo e pelo desenvolvimento de toda a cadeia produtiva em torno da sociedade.

Por tudo isso, conforme Macedo e Avessa (2004), as empresas e as comunidades devem zelar pelo consumo consciente, ou seja, o uso de bens e serviços que atendam às necessidades básicas e tragam uma melhor qualidade de vida à população, ao mesmo tempo que minimizem a utilização de recursos naturais, materiais tóxicos, a emissão de poluentes, de forma a não prejudicar as futuras gerações. Somente assim, as empresas se tornam verdadeiras empresas-cidadãs, gerando consumidores responsáveis e buscando continuamente a solução ou, ao menos, a diminuição das carências sociais existentes.

Nem é preciso ser um bom observador, segundo os autores, para verificar que as empresas socialmente responsáveis, que pensam não somente no lucro, mas, acima de tudo, no ser humano, são mais valorizadas e reconhecidas, com a preferência dos seus clientes. Essas ações estão se transformando numa poderosa vantagem competitiva no desenvolvimento dos negócios das organizações, já que os consumidores valorizam a preocupação das empresas em tornar a sociedade mais equilibrada, com menos injustiças e desigualdades.

\section{8 - Conclusão}


Revista Eletrônica de Ciência Administrativa (RECADM) - ISSN 1677-7387 Faculdade Cenecista de Campo Largo - Coordenação do Curso de Administração v. 4, n. 1, maio/2005 - http://revistas.facecla.com.br/index.php/recadm/

Apesar de responsabilidade social corporativa não ter uma definição única, de aceitação unânime, ela em geral se refere a uma visão de negócio que une o respeito por valores éticos, pelas pessoas, comunidades e meio ambiente.

A responsabilidade social corporativa é vista pelas empresas líderes como mais do que uma coleção de práticas discretas, gestos ocasionais ou iniciativas motivadas pelo marketing, relações públicas ou outros benefícios. Ela é vista como um conjunto abrangente de políticas, práticas e programas integrados às operações do negócio, e processos de tomada de decisão que são apoiados e recompensados pelos dirigentes da empresa.

O que todos esperam das empresas é uma postura comprometida com o desenvolvimento sustentável do país, isto é, que se envolvam principalmente com a proteção do meio ambiente, a redução da pobreza e o aumento da expectativa de vida da população.

A cada ano as empresas descobrem novas formas de administrar de acordo com diretrizes para o desenvolvimento sustentável $\mathrm{Na}$ área científica, são inúmeras as pesquisas voltadas para a preservação da vida no planeta; no campo das políticas públicas, surgem leis que pretendem impedir a depredação ambiental e promover uma atuação mais ética, mais respeitosa para com todos. Cada vez mais surgem, em vários cantos do planeta, movimentos de educação ambiental, preservação cultural e resguardo do patrimônio da humanidade. A relação do homem com a natureza e o seu semelhante está mudando na mesma medida em que cresce o respeito à vida.

Outra questão que surge, ao se falar em desenvolvimento sustentável, é a diminuição das desigualdades econômicas e sociais e também entre as regiões. Já há muita gente consciente de que diminuir a pobreza é um caminho para se proteger o ambiente.

Ao longo da última década, um número crescente de companhias vem reconhecendo os benefícios das políticas e práticas de responsabilidade social corporativa. Suas experiências são amparadas por um corpo também crescente de estudos empíricos que demonstram que a responsabilidade social corporativa tem um impacto positivo no desempenho econômico da empresa e que pode ser medido de várias maneiras.

As companhias também vêm sendo encorajadas a adotar e expandir seus esforços em responsabilidade social corporativa como resultado da pressão dos consumidores, clientes, fornecedores, empregados, comunidades, investidores, organizações ativistas e outros públicos envolvidos.

Como resultado, a responsabilidade social corporativa cresceu dramaticamente nos últimos anos, em companhias de todos os tamanhos e de todos os setores, o que tem levado ao desenvolvimento de estratégias inovadoras nos seus 
Revista Eletrônica de Ciência Administrativa (RECADM) - ISSN 1677-7387

Faculdade Cenecista de Campo Largo - Coordenação do Curso de Administração v. 4, n. 1, maio/2005 - http://revistas.facecla.com.br/index.php/recadm/

programas, em áreas como ética de negócio, ambiente de trabalho, meio ambiente, marketing responsável e envolvimento comunitário.

Hoje, de acordo com o Guia Conceitual e Prático da Uniethos (2004), não é mais possível pensar em um estabelecimento só como meio de obter lucros, mas como parte de um projeto maior, capaz de levar benefícios a todos e alcançando sempre melhores resultados. O sucesso do seu negócio também depende de uma troca responsável com o mundo à sua volta e do respeito por quem trabalha com você.

\section{Referências}

AECA -Asociación Española de Contabilidad y Administración de Empresas. Documentos AECA serie Responsabilidad Social Corporativa. Marco Conceptual de la Responsabilidad Social Corporativa. Documento n 1. Madrid - España, 2004.

ALMEIDA, F. Gestão do Desenvolvimento Sustentável na Indústria Eletroeletrônica http://www.tec.abinee.org.br/2003/arquivos/s902.pdf - 10/2003. Acesso em 28/12/2004.

GONZÁLEZ, C. L. ABADÍA, J. M. M. Global Reporting Iniciative: Contabilidad y Sostenibilidad. Revista Partida Doble. n. 135, p. 80-87, jul/ago. 2002. www.partidadoble.es. Acesso em 15/06/2003.

GRASSI, M. R. A Universidade frente aos desafios da Sustentabilidade: um debate sobre a construção do futuro.Painel: o conhecimento pertinente e a formação do cidadão que desejamos.

UFRGS, 8 de setembro de 2004. www.inisustentavel.ea.ufrgs.br. Acesso em 29 de dezembro de 2004.

GUIA Conceitual e Prático Ethos/ABIP - Associação Brasileira da Indústria de Panificação e Confeitaria. Responsabilidade Social Empresarial nas Organizações de Varejo. Setor de Panificação http://www.uniethos.org.br/ Uniethos/documents/guia rse panificacao.pdf. Acesso em 29/12/2004.

INSTITUTO ETHOS. Como as empresas podem implementar programas de voluntariado. São Paulo, 2001. 121p.

MACEDO, L. C. de. AVERSA, M. B. A Contribuição das Relações Públicas para a Criação da Empresa-Cidadã

http://www.portal-rp.com.br/bibliotecavirtual/responsabilidadesocial/0134.htm. Acesso em 23/12/2004.

REVISTA Exame. Guia de boa cidadania corporativa, 2001. São Paulo. n. 754, nov. 2001.

SCHOMMER, P. C.; ROCHA, A. G. P.; FISCHER, T.. Cidadania Empresarial no Brasil: Três organizações baianas entre o mercado e o terceiro setor. In: XXIII ENCONTRO 
Revista Eletrônica de Ciência Administrativa (RECADM) - ISSN 1677-7387

Faculdade Cenecista de Campo Largo - Coordenação do Curso de Administração v. 4, n. 1, maio/2005 - http://revistas.facecla.com.br/index.php/recadm/

NACIONAL, 1999, Foz do Iguaçu/PR. Anais... Foz do Iguaçu: Associação nacional dos programas de pós- graduação em Administração (ANPAD), 1999.

YOUNG, R. Gestão da responsabilidade social e do desenvolvimento sustentável. http://www.uniethos.org.br/DesktopDefault.aspx?TabID=3888\&Alias=uniethos\&Lang=ptBR. Acesso em 29/12/2004.

www.ethos.org.br. Indicadores Ethos de responsabilidade Social Empresarial, versão 2003. Acesso em 01/11/2004.

www.ethos.org.br/ Uniethos Resultado Adicional Indicadores Ethos Aplicados ao Princípio do Pacto Global. Acesso em 10/11/2004.

http://www.observatoriosocial.org.br/ Responsabilidade Social Empresarial: perspectivas para a atuação sindical. Acesso em 23/12/2004.

http://www.pactoglobal.org.br/ Manual do Global Compact: Entendimento Prático da Visão e dos Princípios. Acesso em 22/12/2004.

http://europa.eu.int/comm/employment social/soc-dial/csr/csr2002 pt.pdf. Comunicação da Comissão relativa à Responsabilidade Social das Empresas: um contributo das empresas para o desenvolvimento sustentável. Acesso em 20/12/2004.

http://europa.eu.int/comm/environment/liability/el full_pt.pdf. Livro Branco sobre Responsabilidade Ambiental. Acesso em 26/12/2004.

http://europa.eu.int/comm/employment social/publications/2001/ke3701590 pt.

Livro Verde Promover um quadro europeu para a responsabilidade social das empresas. Acesso em 26/12/2004.

http://www.globalreporting.org/guidelines/2002/2002Portuguese B.pdf Diretrizes para Relatórios de Sustentabilidade - GRI 2002. Acesso em 2/12/2004.

http://www.balancosocial.org.br/cgi/cgilua.exe/sys/start.htm?sid=21

Social

Accountability $\mathbf{8 0 0 0}$ (SA 8000) Acesso em 28/12/2004.

http://www.bsd-net.com/bsd brasil/handbookaa1000.pdf AA1000: Estrutura de gestão da responsabilidade corporativa Acesso em 28/12/2004.

http://www.oitbrasil.org.br. Acesso em 20/12/2004. 